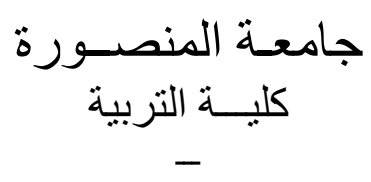

\title{
فعالية استراتيجية العصف الذهني التعاوني في تنمية ههارات التفكير الناقد في الرياضيات لدي تلاهيذ المرحلة الإعدادية مختلفى السعة العقلية.
}

$$
\begin{aligned}
& \text { إعداد } \\
& \text { الباحث / أحمد ممدوح الصناوي طلبه بإيه } \\
& \text { معلم رياضيات بإدارة شرق التعليمية بالمنصورة المدي طدا } \\
& \text { أ.د/ محمد عبد السميع رزق النف }
\end{aligned}
$$

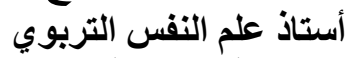

$$
\begin{aligned}
& \text { كليه التربية - جامعة|لمنصورة التربوية } \\
& \text { إشر افت } \\
& \text { أ.د/ رمضان صالح رمضان }
\end{aligned}
$$

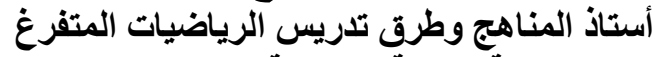

$$
\begin{aligned}
& \text { كلية التربية - جامعة المنصورة }
\end{aligned}
$$

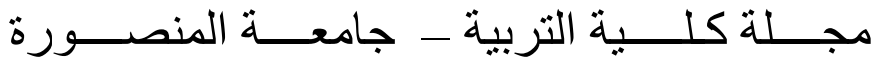

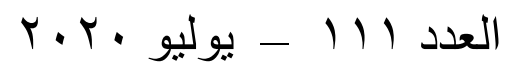


فعالية استر اتيجية العصف الذهني التعاوني في تتمية مهار ات التفكير الناقد في الرياضيات لدي تلاميذ المرحلة الإعدادية مختلفى السعة العقلية تئية

\section{أحمد ممدوح الصاوي طلبه}

المستخلص

استهف البحث الحالي التعرف على فعالية استراتجية العصف الذهني التعاونسي في تنمية مهالات

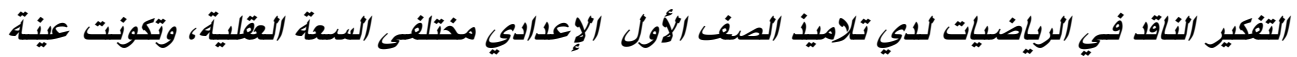

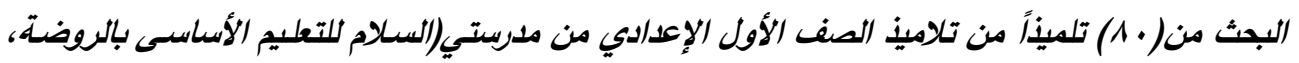

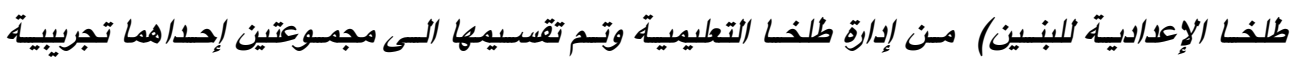

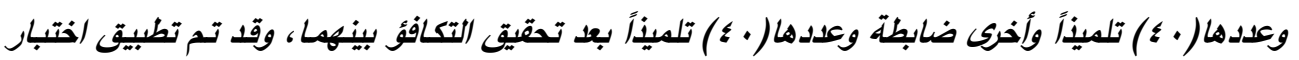

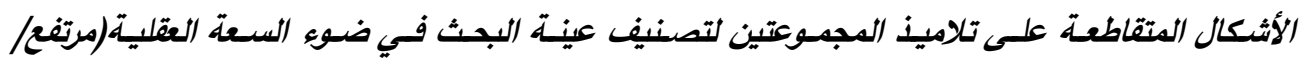

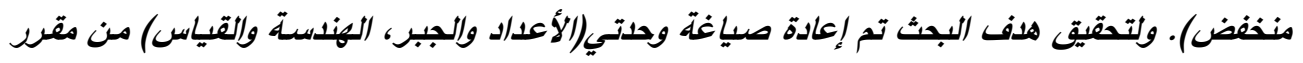

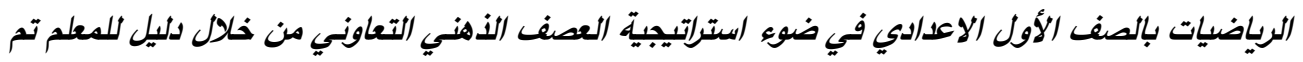

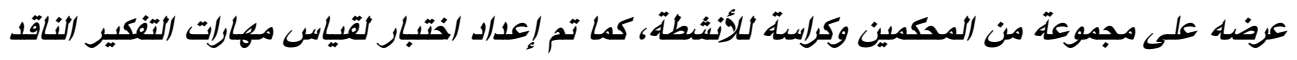

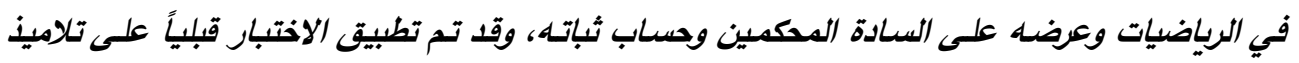

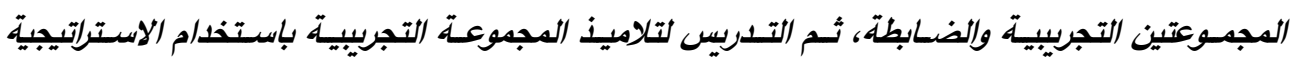

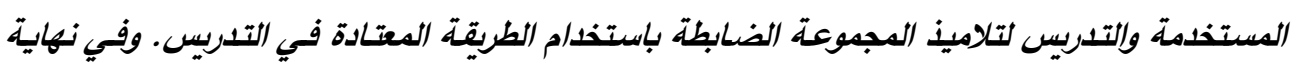
التجببة تم إعادة تطبيق اختبار التفكير الناقد في الرياضيات بعدياً على تلاميذ المجدوعتين التجريبية والضابطة وقد أسفرت نتائج البجث عن الآتسي:

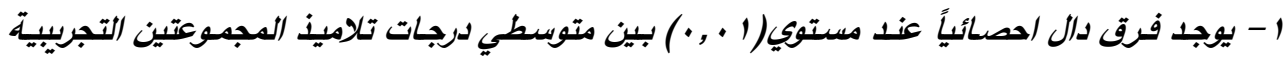

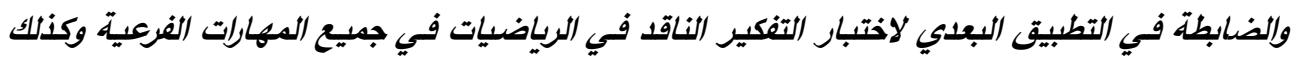
اللرجة الكلية لصاتح تلاميذ المجموعة التجربيية(بغض التطبية النظر عن مستوي السعتة العقلية).

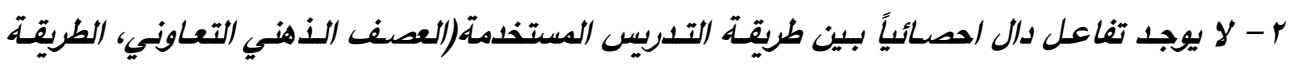

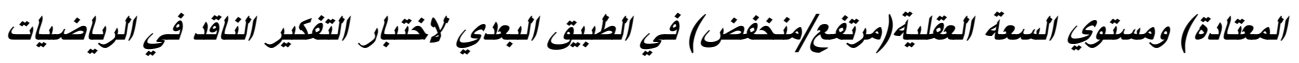
في جميع الههارات الفرعية وكنلك اللدرجة الكلية.

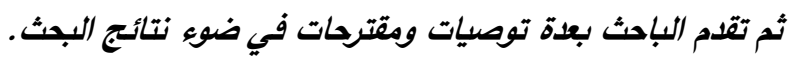

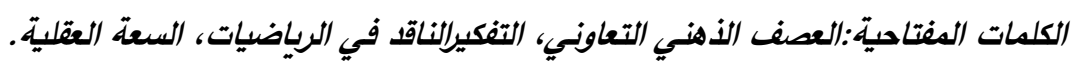


تعد الرياضيات من المقررات الهامة التى تقود إلى تنمية التفكير لاي التلاميذ في مختلف مراحلهم العمرية، لأنها تتميز بطبيعة تجعل منها مجالاً خصباً لتنمية قدرة التلاميذ على التفكير بما تحويه من مشكلات تثير تفكيرهم وتتحدي ذكاءهم وبما تتطلبه من اجراء عمليات عقلية عليا، كما أن المواقف والمثكلات الرياضية تتطلب من التلميذ عند مواجهتها ومحاولية حلها ممارسـة

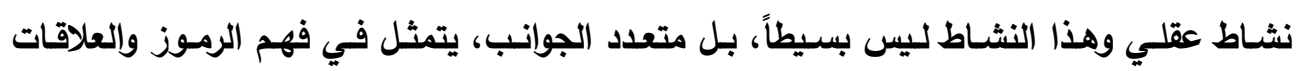

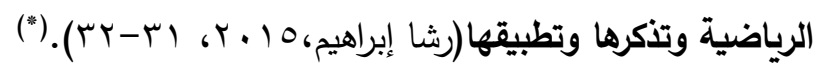
وقد تنافس التربويون في استخدام طرق حديثة ومتنوعة لتحسين مخرجات التعليم، لأن

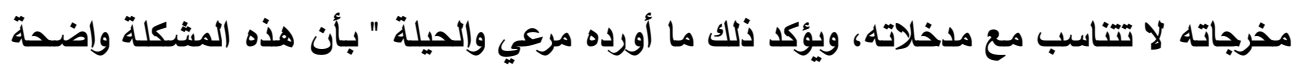

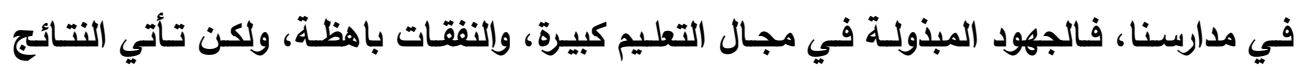

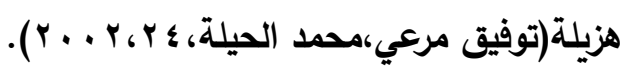

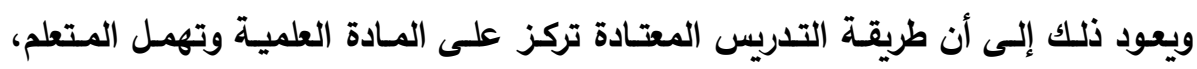

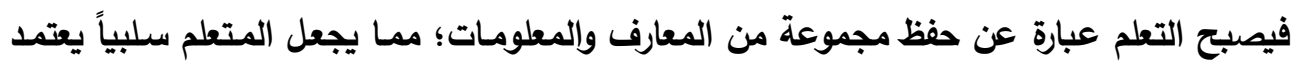
على الحفظ الآلي، فيعيه أهية كبيرة، ويركز جهاه في السيطرة على المادة، بهدف الاحتفاظ بها واسترجاعها عند الحاجـة، هذا في جميع المقررات بصفة عامـة وفي الرياضيات بصفة خاصـة.

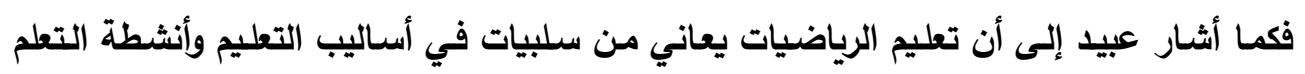

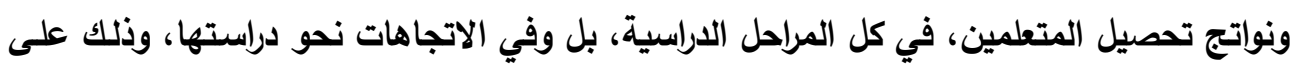

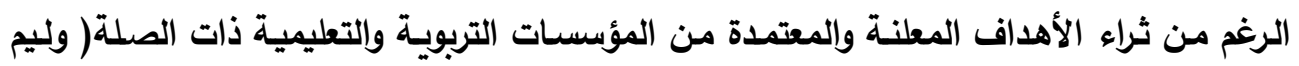

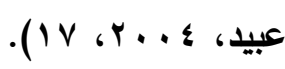
لذا بأ اهتمام كثير من التربويين في العمل على تطوير أسـاليب التدريس التي تعمل على

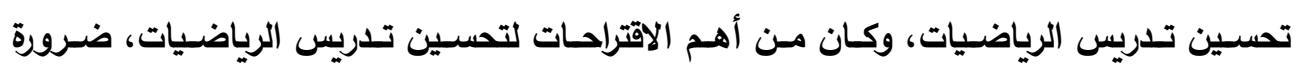
استخدام استراتيجيات التعلم النشط، ومن هذه الاستراتيجيات العصف الذئن الذهي والتعلم التعاوني.

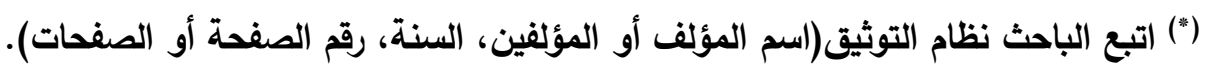
هذا ويعد العصف الذهني إحدى استراتيجيات التدريس الهامـة التي تساعد التلاميذ على التى توليد الأفكار وتنمية مهارات التفكير الناقد والابداعي وتدور هذه الاستراتيجية حول مشكلة قابلة

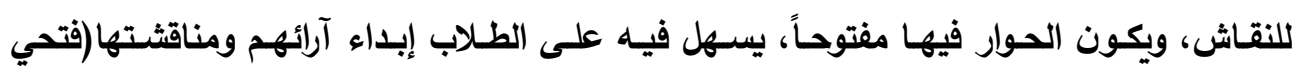

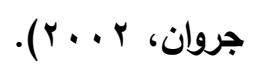


ويبين أوزبورن Osborn أن استراتيجية العصف الذهني تعدل من ازدياد تأثير الرؤية النقدية

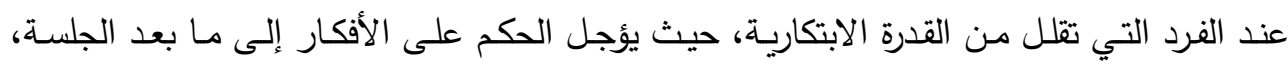
فيتحرر العقل ويتحرك في جوانب عدة ويتعمق فيها للبحث عن فكرة تحل المشكلة لذا تكون الأفكار الغزيرة ذات قيمة عالية في هذه الاستراتيجية(Christina,2004).

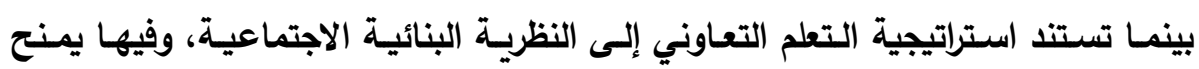

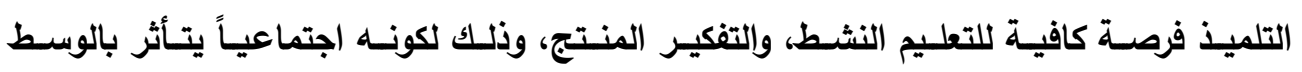

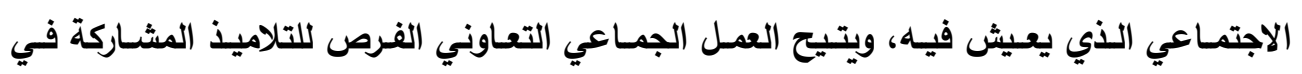

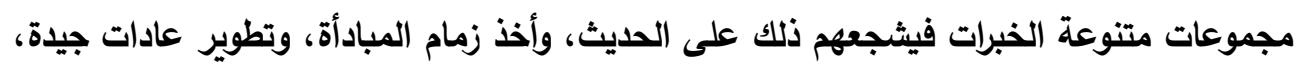

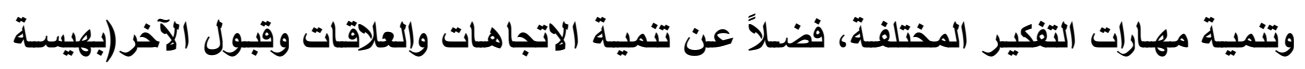

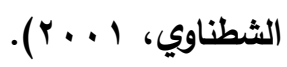

وقد لاحظ الباحث من خلال تدريسه للرياضيات أن الجمع بين هاتين الاستراتيجيتين بشكل

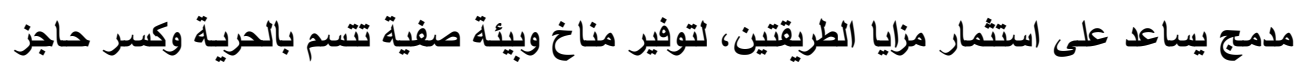

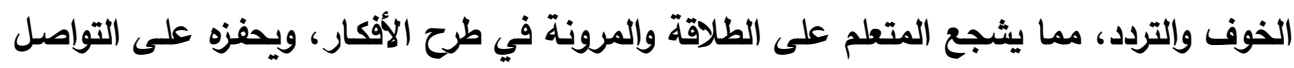

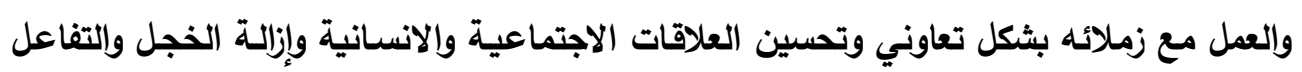

ومن هنا جاءت محاولة الامج بين استراتيجيتي العصف الذهني و التعلم التعاوني، حيث بثكل إيجابي.

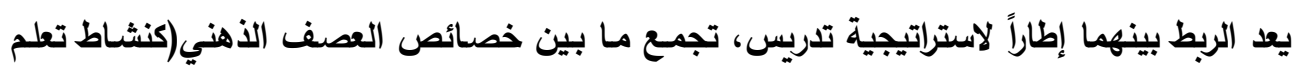

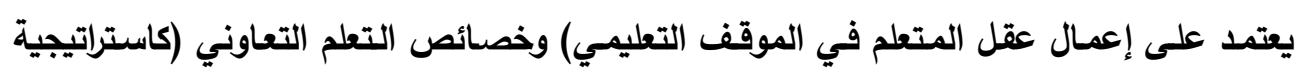

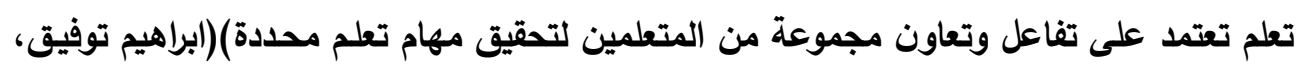

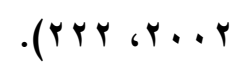
كمـا أن مصطلح السـعة العقليـة استخدمه علمـاء التربية وعلـم النفس في التعبير عن

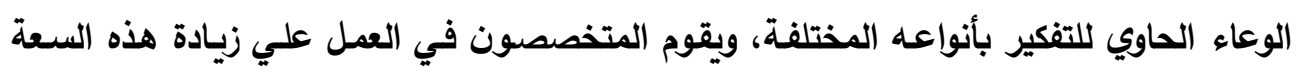

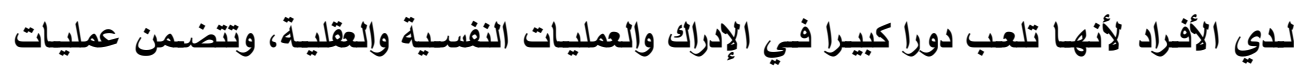

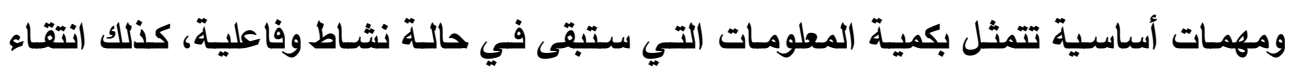

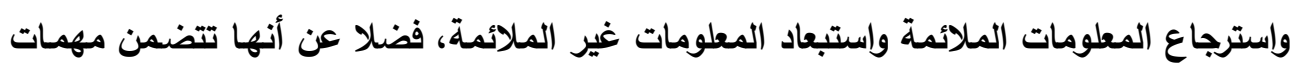
التخطيط وتوجيه الأداء. 
وإن واحدة من أكبر التحديات التي تواجه أي نظام تربوي في العالم هو القدرة على تعليم

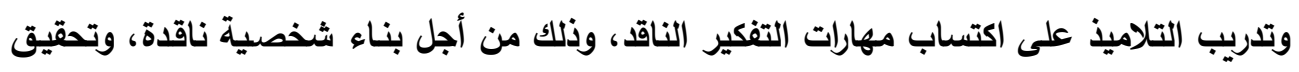

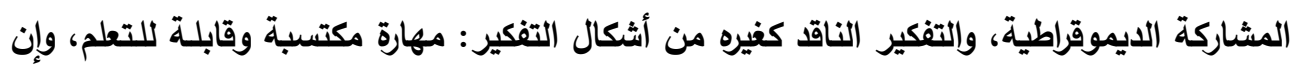
التفكير الناقد يعتبر هدفاً أساسياً يجب السعي لتحقيقه في الوقت الحاضر ، ذلك لمساعدة التلاميذ

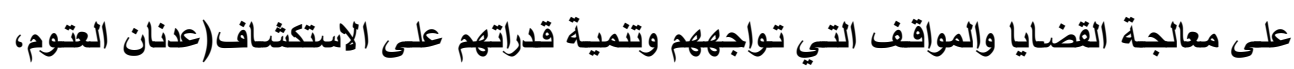
$\cdot(r) \cdot, r . . \varepsilon$

ونجاح المعلم في تنمية التفكير الناقد لاى تلاميذه يتوقف بدرجـة كبيرة على مدى نجاحه

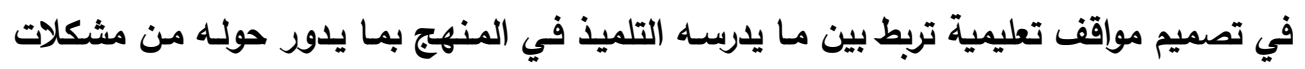

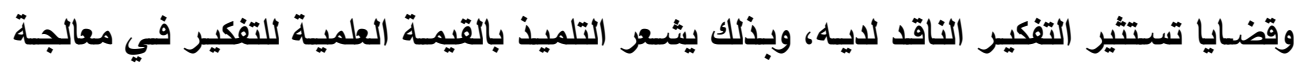
الأمور والمواقف والأحداث المحيطة به.

لذا كان من أهم أهداف الرياضيات هو تعليم التلاميذ وتدريبهم على النقد المدعم بالحجج والأدلة وذلك للوصول إلى الحقائق و التعليمات والتعرف على العلاقات بينها، والتمييز بينها وبين الآراء وإلتأكد من صدق المصادر وصحتها و القدرة على التفسير والتحليل وإلتركيب.

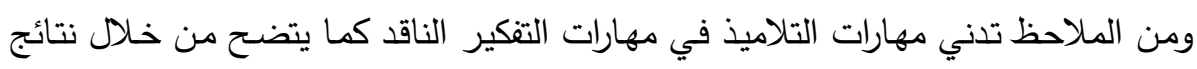

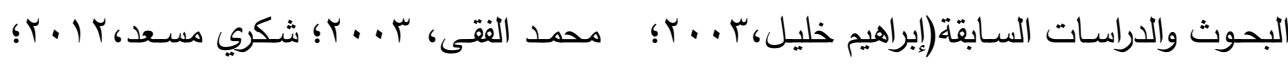

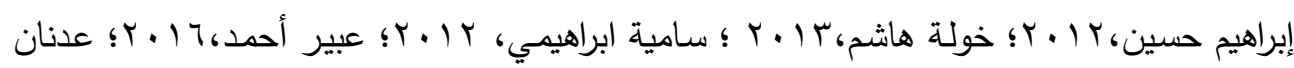

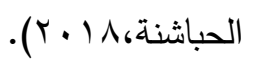

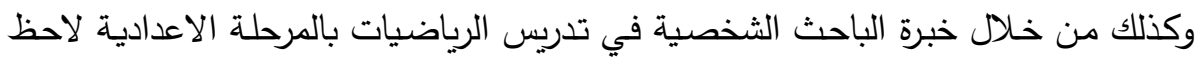

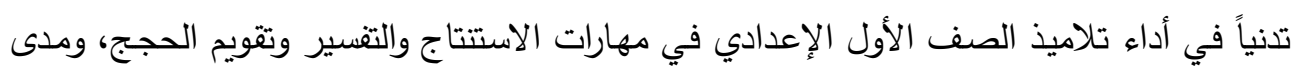

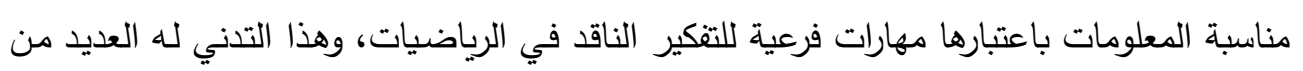

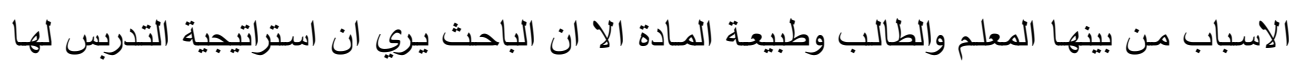
الدور الاكبر في هذا التدني. لذا اقترح الباحث استراتيجية تجمع بين العصف الذهني والتعلم التعاوني في محاولة منـه لعلاج هذا التدني. وفي ضوء نتائج هذه البحوث والدراسات يتضح أن زيادة السعة العقلية عامل مؤثر في توليد

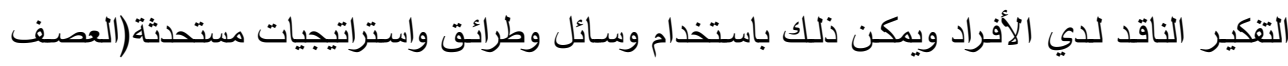


الذهني التعاونى) في هذا البحث مما يساعد على تتظيم المعلومات،واستخدامها الاستخدام الأمثل لتتمية مهارات التفكيرالناقد. الإحساس بالمشكلة: نبع إحساس الباحث بمشكلة البحث الحالي من خلال عدة مصادر أساسية وهي:

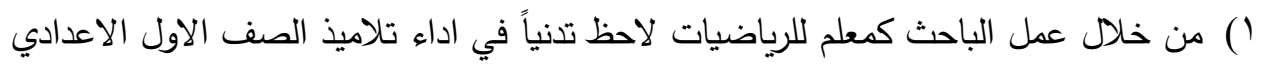
في مهارات الاستتاج والتقسير وتقويم الحجج ومدي مناسبة المعلومات كمهارات فرعية للتفكير

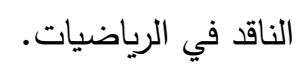

r ن نتائج البحوث والدراسات السابقة حيث اشارت العديد من هذه البحوث والدراسات الي تدني

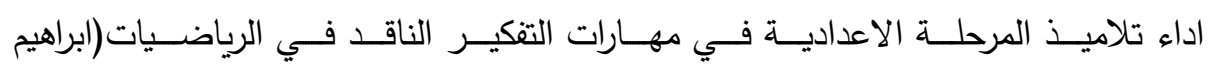

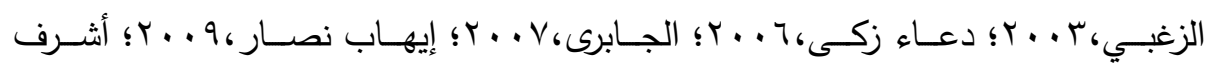

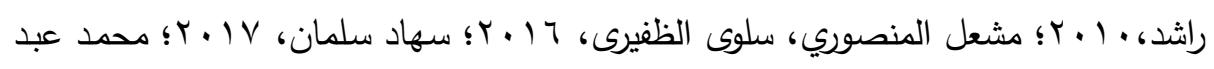

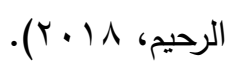

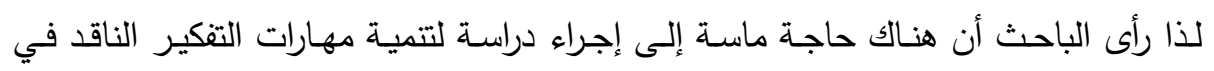

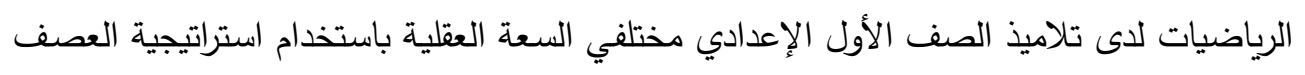
الذهني التعاوني. مشكلة البحث:

تمثلت مشكلة البحث الحسالي في تدني مستوى أداء تلاميذ الصف الأول الإعدادي في مهارات التفكير الناقد ويمكن صياغة المشكلة في التساؤل الرئيسى الأتي:

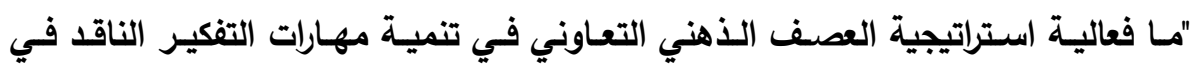
الرياضيات لاي تلاميذ الصف الأول الإعدادي مختلفي السعة العقلية؟ ويتفرع من هذا التساؤل الرئيس الأسئلة الفرعية التالية:

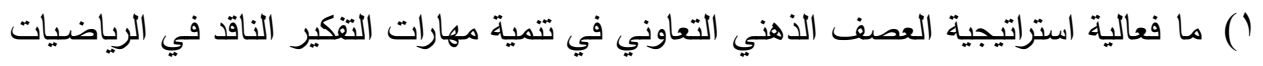

لاى تلاميذ الصف الأول الإعدادي (بغض النظر عن مستوي السعة العقلية لديهم)؟

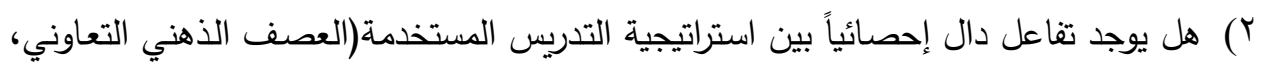

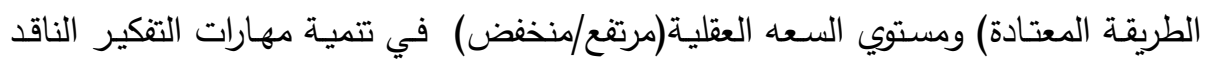

$$
\begin{aligned}
& \text { لاى تلاميذ الصف الأول الإعدادي؟ } \\
& \text { أهداف البحث: أنات } \\
& \text { تمثلت أهداف البحث الحالي في: }
\end{aligned}
$$




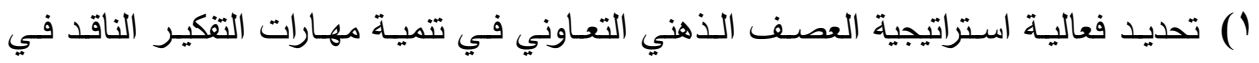

$$
\text { الرياضيات لاى تلاميذ الصف الأول الإعدادي. }
$$

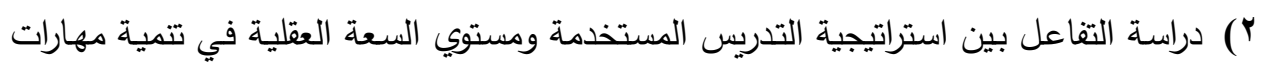

$$
\text { التفكير الناقد في الرياضيات لاى تلاميذ الصف الأول الإعدادي. }
$$

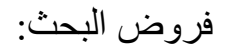

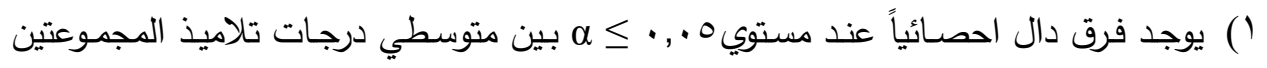

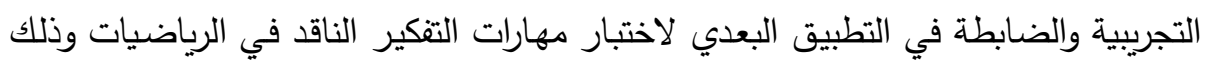
لصالح تلاميذ المجموعة التجريبية.

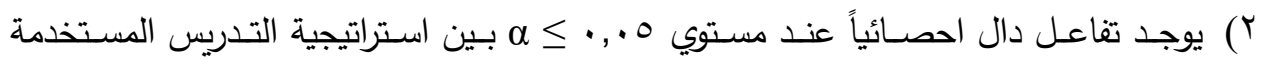

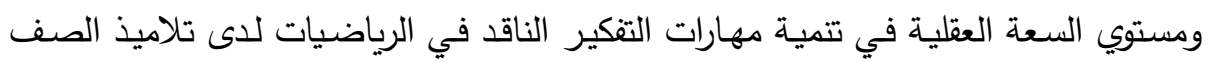

$$
\text { أهية البحث: الأول الإعدادي. }
$$

( ) تتمية أداء تلاميذ الصف الأول الإعدادي في مهارات التفكير الناقد في الرياضيات.

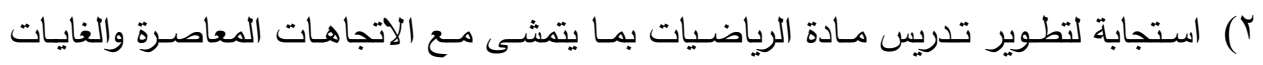

$$
\text { التربوية المنشودة. }
$$

r) توجيه أنظار مخططي مناهج الرياضيات الى استخدام استراتيجية العصف الذهني التعاونى

$$
\text { كإحدى استراتيجيات التدريس عند تطوير مناهج الرياضيات. }
$$

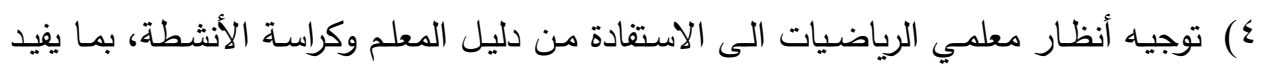

معلمي ومعلمات الرياضيات في التدريس مما يدفعهم إلى تطوير أدائهم التدريسي.

0) فتح المجال أمام الباحثين باستكمال بحوثهم في هذا الموضونئ. حدود البحث:

$$
\text { تمثلت حدود البحث في التالي: }
$$

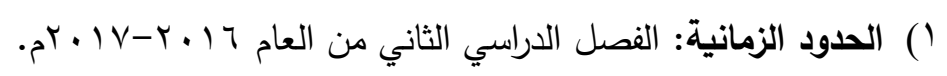

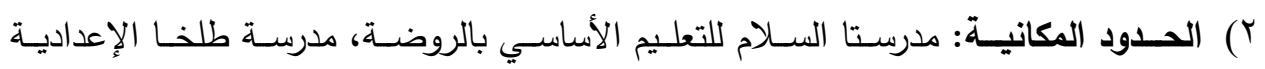

للبنين(إدارة طلخا التعليمية- مديرية التربية والتعليم بمحافظة الدقهلية).

$$
\text { r) الحدود الموضوعية: وتمثلت في الآتي: }
$$


- وحدتي (الأعداد والجبـر ، الهندسـة والقيـاس) مـن محتوى الرياضـيات للصـف الأول الإعدادي

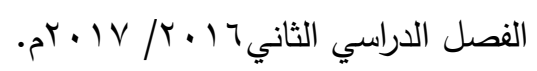

- أربع مهارات من مهارات التفكير الناقد وهى(الإستتتاج، التقسير ، تقويم الحجج، مدى مناسبة المعلومات).

ع) الحدود البثـرية:عينـة مـن تلاميذ الصف الأول الإعدادي بادارة طلذا التعليمية بمحافظـة

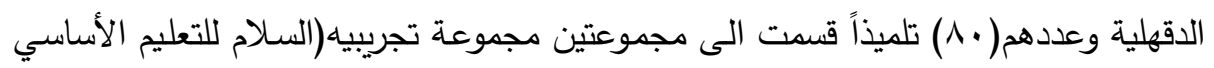

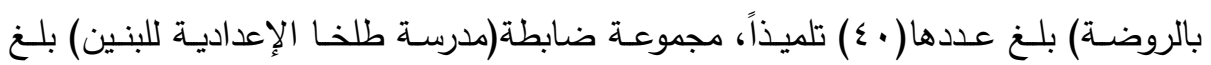

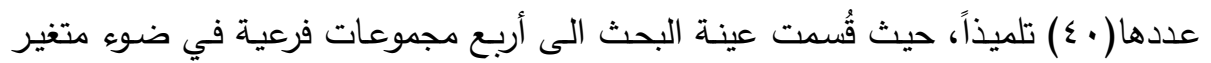
السعه العقلية لديهم(مرتفع/منخفض). 0) التتافس الجمعي كأحد أشكال التعلم التعاوني. مو اد و أدو ات البحث: مواد البحث وتمثلت في الآتي: - دليل المعلم في وحدتي(الأعداد والجبر ، الهندسة والقياس) باستخدام استراتيجية العصف الذهني التعاوني. - كراسه نشاط التلميذ في وحدتي (الأعداد والجبر ، الهندسة والقياس). أدوات البحث وتمثلت في الآتي: - اختبار التفكير الناقد في الرياضيات(من إعداد الباحث). - - اختبار الأشكال المتقاطعة لمقياس السعة العقلية إعداد جان باسكاليونى، ترجمة(اسعاد البنا،

$$
\text { منهج البحث: حمدي البنا، ـ99 (19). }
$$

استحدم الباحث المنهج شبه التجريبي: وذلك لتحديد فعالية استراتيجية العصف الذهني

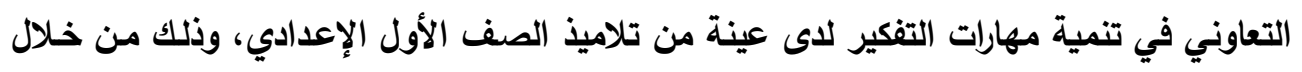
تقسيم عينة البحث إلى مجموعتين إحداهما تجريبية والأخرى ضابطة، وتطبيق أداة البحث قبل تلبياً

$$
\text { وبعدياً. }
$$

1- استراتيجية العصف الذهني التعاونى( Cooperative Brainstorming):

يعرفها الباحث إجرائياً بأنها: دمه لاستراتيجتي العصف الذهني والتعلم التعاوني معاً وتتمثل

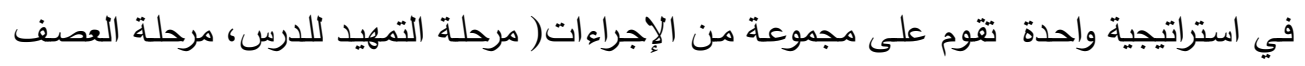


الذهنى والمجموعات الصغيرة، التحقق من صحة الأفكار ) التي يستخدمها معلم الرياضيات لتدريس وحدتي (الأعداد والجبر , الهندسة والقياس).

r- التفكير الناقد ( Critical Thinking):

يعرفـه الباحث إجرائياً بأنـه: أحد أنـواع التفكير التى تتعلق بإصـدار حكم على شـيء مـا

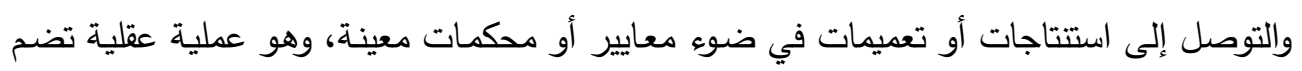

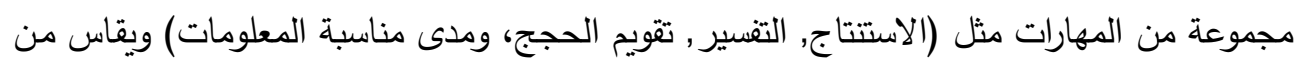
خلال درجة التلميذ التى حصل عليها في اختبار التنكير الناقد في الرياضيات الذى أعده الباحث لهذا الغرض في البحث الحالي. ب- السعة العقلية(Mental Capacity):

يعرفها الباحث إجرائيـاً: بأنها جـزه محدود مـن الذاكرة يتم فيهـا معالجـة كل المعلومـات المستقبلة والمسترجعة في وقت واحد، وتمثل العدد الأقصى من المخططات التي يستطيع العقل

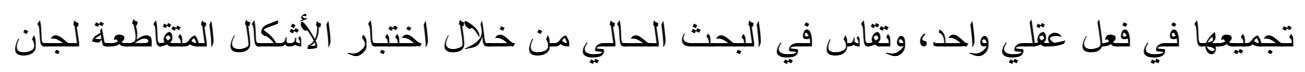
بسكاليوني ترجمة(حمدى البنا،إسعاد البنا، ـ99 و (19) ).

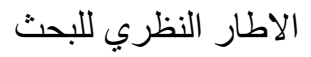
المحور الأول: استراتيجية العصف الأهني التعاوني:

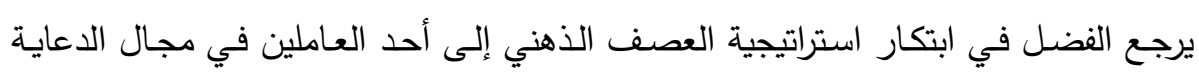
والإعلان يدعى أليكس أوزبورن (Alex Osborn) عندما أراد أن يغير من روتينية الاجتماعات التهات

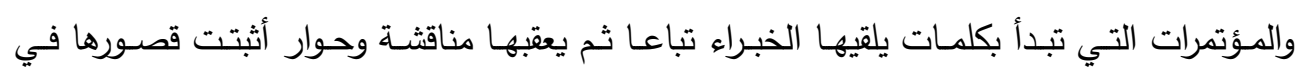
الوصول للحلول الابتكارية للمشكلات المطروحة. ومن أهداف العصف الذهني ما يلي:

(الخروج على المألوف وتقديم الجديد، مضاعفة عدد الأفكار المقدمة من وجود المجموعة،

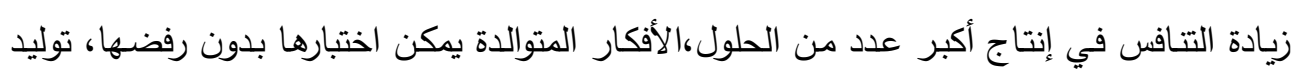

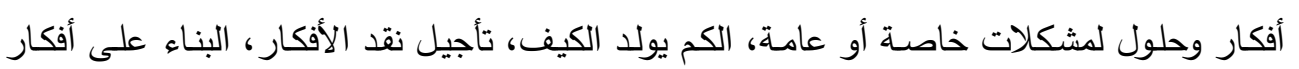

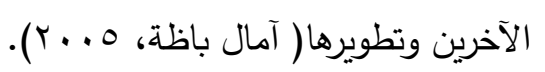

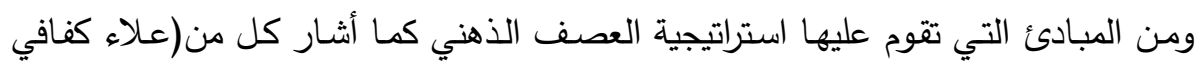

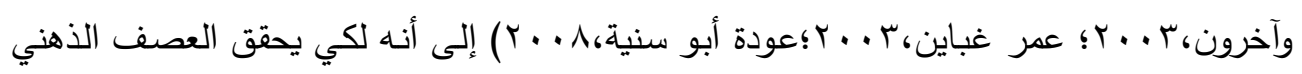
أهدافه يجب الالتزام بمبدأين أساسيين وهما: 


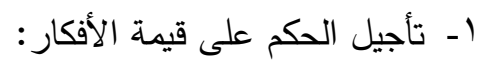

وهذا يجعل الأفكار أكثر تدفقًا وسيولة؛ لأن الحكم السريع على الأفكار يحدد عملية تدفقها

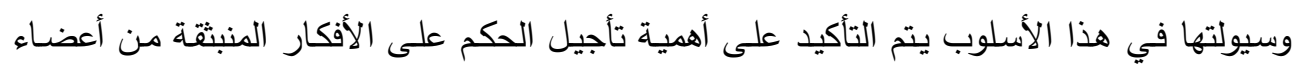
جلسة العصف الذهني، وذلك في صالح تلقائية الأفكار وبنائها ، فإحساس الفرد بأن أفكاره ستكون

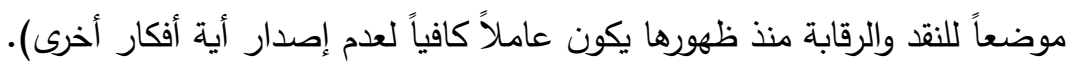

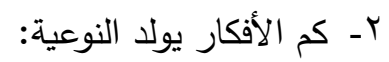

قاعدة الكم يولد الكيف ، والتي ترى أن الأفكار مرتبة في شكل هرمي وأن أكثر الأفكار

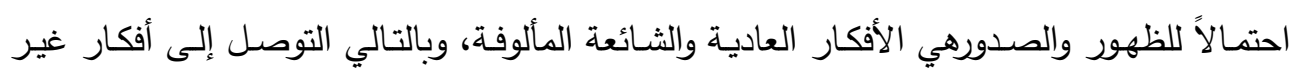
العادية والأصيلة و بالتالي تزداد كمية الأفكار .

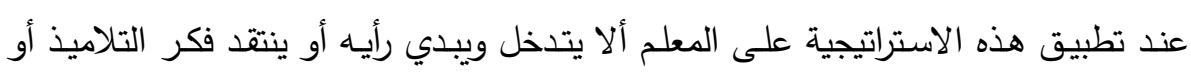

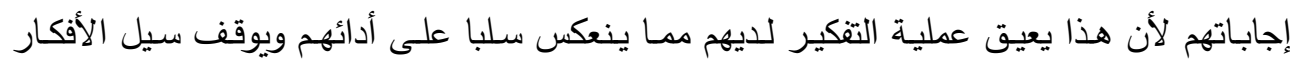

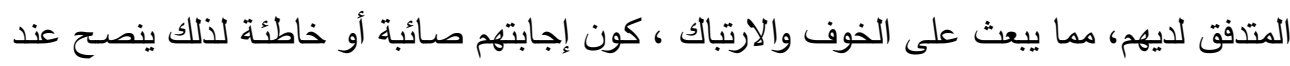
التطبيق سماع كم اكبر من الأفكار للوصول إلى الأفكار العادية والأصيلة. التعلم التعاوني: (التطيق سماع

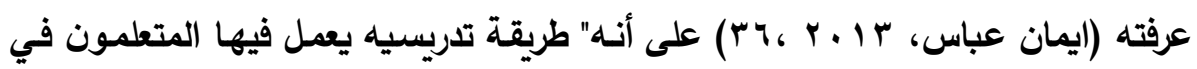

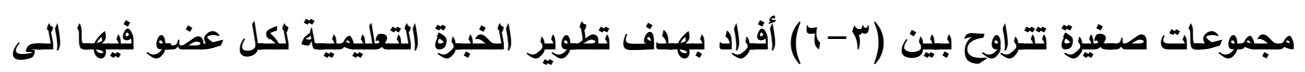
أقصى حد ممكن".

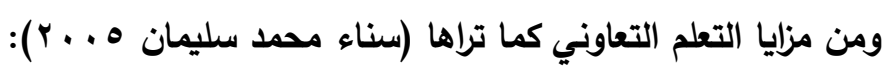

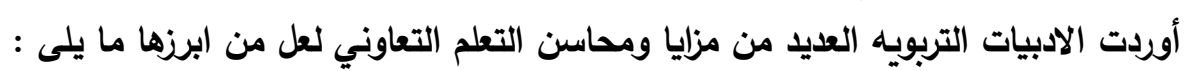
1- التعلم التعاونى صالح لمختلف المواد الدراسيه (الرياضيات ،العلوم،اللغات.....الخ).

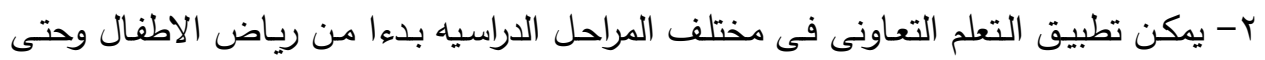

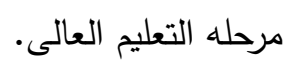
r- لايحتاج الى امكانيات ماديه كبيره لتطبيقه ويوفر التكاليف فى الاجهزه والادوات والخامـات المستخدمه فى المواقف التعليميه. ع - يقلل من الفتره الزمنيه التى يعرض منها المعلم المعلومات وكذا من جهده فى متابعه وعلاج الطلاب منخفضى التحصيل. 0- يحد من الإحساس بالخوف والقلق الذى قد يصاحب عمليه التعلم. 
7- ينمى المهارات الاجتماعيه لدى الطلاب والعلاقات الايجابيه بينهم.

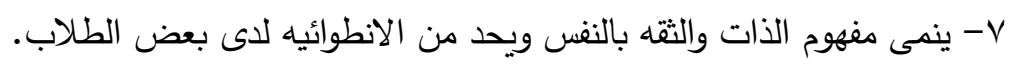

1 - ينمى مهارات التقكير العليا.

العصف الذهني التعاوني:

يستخدم هذا الأسلوب عندما يكون هناك رغبـة عالية من الإبداع، كي يتمكن المتعلمين

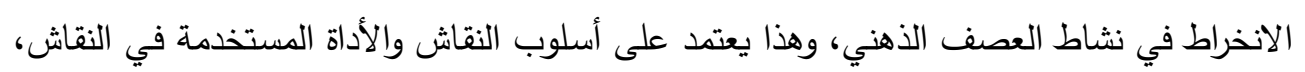
بحيث ينطلق قائد النقاش دائماً بعرض مشكلة موضوع البحث باختصار ، قدأ تد تكون سعلة أو معقدة،

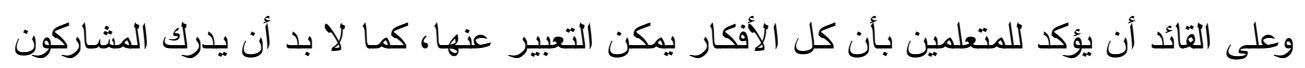
في المجموعة أن كم الاقتراحات ووفرتها أمر بالغ الأهمية. العصف الذهني التعاوني وتدريس الرياضيات:

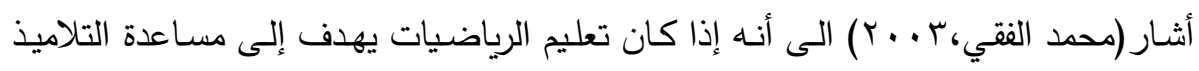
على التنكير الرياضـي وفهم العلاقـات والارتباطـات بـين مختلف الحقـائق والعمليـات الرياضـية، وإمكانية تطبيق المعرفة الرياضية بصورة واضحة، ومن خلال فهم واعي، فانه بناءاً على ذلك يمكن توظيف التعلم التعاوني في تعليم الرياضيات داخل الصف الدراسي. لوني. العصف الذهني التعاوني كاستراتيجية تدريسية لتنمية التفكير الناقد:

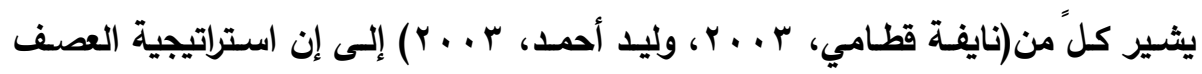
الذهني استراتيجية معرفية، تقوم على التحفيز والحث على التفكير والعمليات العقلية، من خـلاله

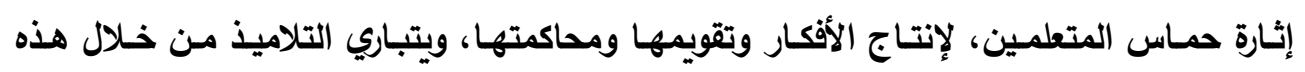

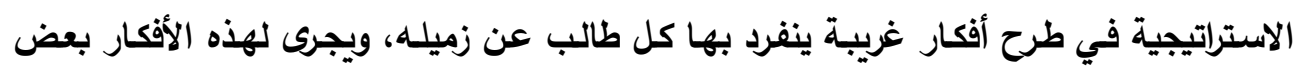

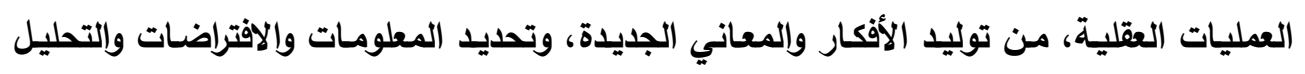

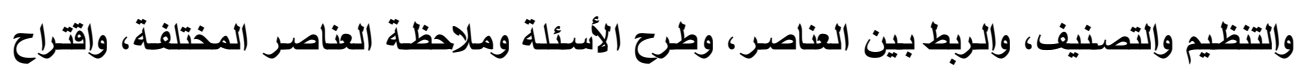

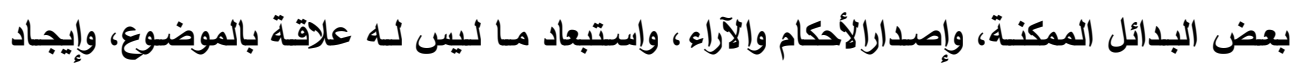

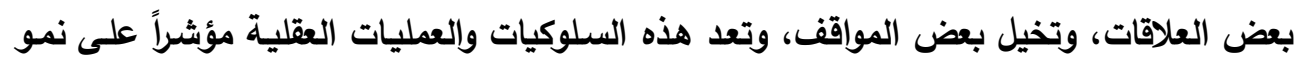
التفكير الناقد لاى التلاميذ.

وتحفـز هـذه الاسـتراتيجية التفكير لـى التلاميــ وتنميـه، وتقـوم على تشـيعهم أفـراداً

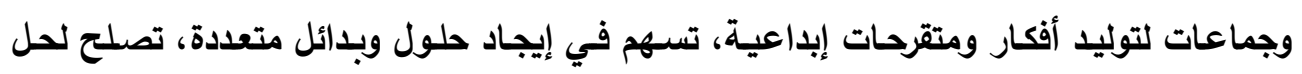

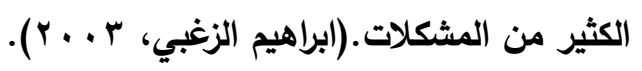


وتوجد العديد مـن البحوث والدراسـات السـابقة التي تناولت استراتيجية العصف الذهني والتعلم التعاوني في تدريس الرياضيات :

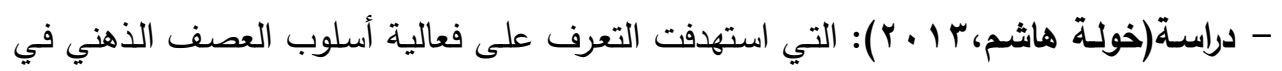
تحصيل طلبة المرحلة الأولى في المعهد التقني- البصرة في مادة الرياضيات، وقد بينت النتائج

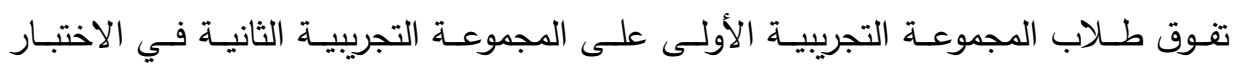
التحصيلي. - دراسة(زينب عثمان 17 ـ ب): التي هدفت إلى توضيح فعالية طريقة العصف الذهني في تحقيق الأهداف المعرفية في تدريس الرياضيات في الصف الثاني الثانوي واستخدمت الباحثة اختبار

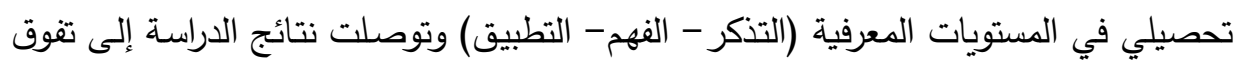
طريقة العصف الذهني على الطريقة التقليدية في تحسين تحصيل التلاميذ والطالبات في مادة الرياضيات.

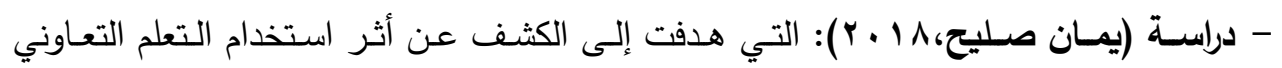
المحوسب على التحصيل الدراسي لطلبة الصف الثامن الاساسي في مادة الرياضيات، وتمثلت أداة الدراسة في اختبار تحصيلي، وتوصلت نتائج الدراسة الي وجود فروق ذات دلالة إحصائية بين درجات التحصيل للطلبة الذين تعلموا عن طريق التعلم التعاوني المحوسب مقارنة وتئ بالطلبة

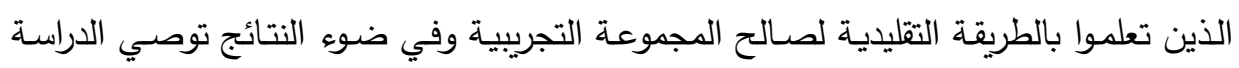

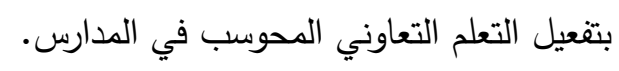
• خ المحور الثاني: التفكير الناقد: عرف أنيس( Ennis,2004) التفكير الناقد بأنـه تفكير منطقي تأملي يعتمد على وضـع فرضيات وصياغة أسئلة ويجربها, وهذا النوع من التفكير يقرر ما قد تؤمن به وما تفعله.

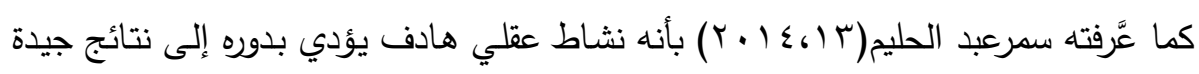

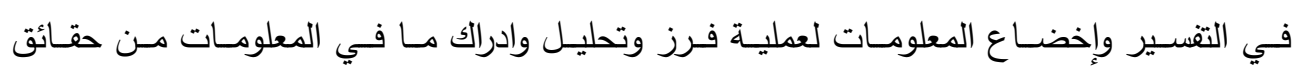

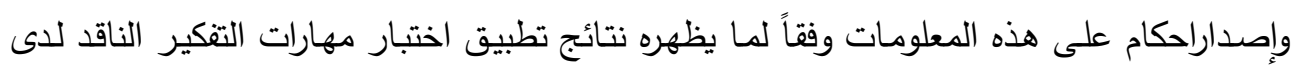
طلاب الصف الثاني الاعدادي. مهارات التفكير الناقد: - الاستنتاج : يعني القدرة على تمييز درجة احتمال صحة أو خطأ استتتاج معين بنـاءاً على المعلومات المتاحة. 
- التفسير: يعني قدرة الفرد على استخلاص نتيجة معينة من حقائق مفترضـة بدرجة معقولة من

$$
\text { اليقين بناء على بعض المعلومات المتاحة. }
$$

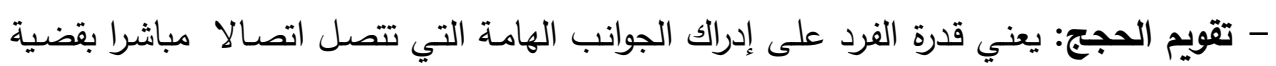

ما، ويمكن تمييز نواحي القوة والضعف منها.

- مـدى مناسـبة المعلومـات: يعني قدرة الفرد على فحص بعض ولع المعلومـات المتاحسة وتحديد

المعلومات المتتاسبه مع بعضها البعض والمعلومات الغير متتاسبة.

ويقاس من خلال درجة التلميذ التى حصل عليها في اختبار التنكير الناقد في الرياضيات

الألى أعده الباحث لهذا الغرض.

خ خ خائص التفكير الناقد:

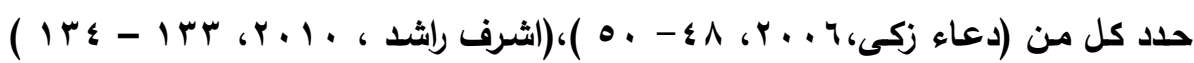

أمكن تحديد خصائص التفكير الناقد بما يلى:

(التفكير الناقد نشـاط ايجابى خلاق، التفكير الناقد عملية وليس نتاجاً فقط، التفكير الناقد

نثاط انفعالى وعقلاني معا، يستثار التفكيرالناقد بالاحداث السلبية والايجابية، يتغير التعبير عن

التفكير الناقد بتغير السياق).

شروط التفكير الناقد: كما حددها جلاسر ( Glazer , E E03).

( ) موقف غير مألوف حيث لا يفهم الفرد المفهوم الرياضى مباشرة أو يفهم كيفية حل المشكلة. Y ) وجود اما تعميم و برهان او تقييم. (Y موفيز.

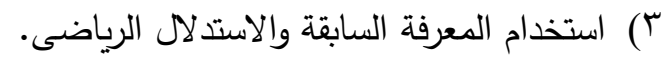

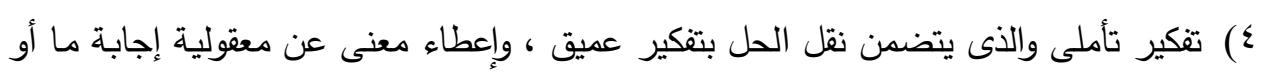

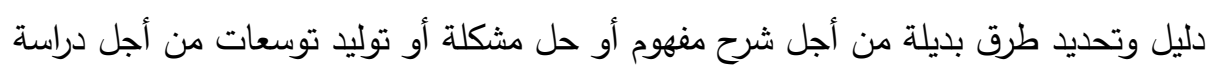

بعض الاراسات التي اهتمت بتنمية التفكير الناقد:

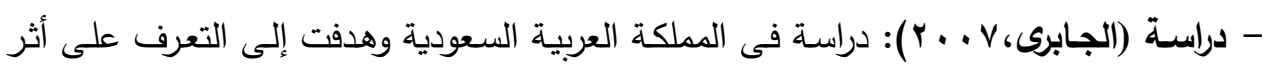

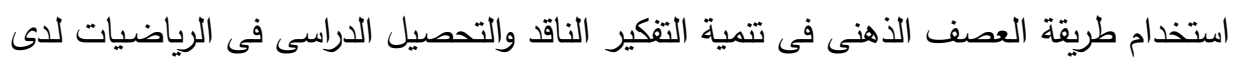

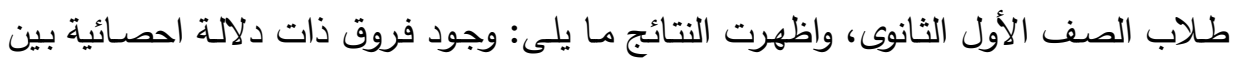

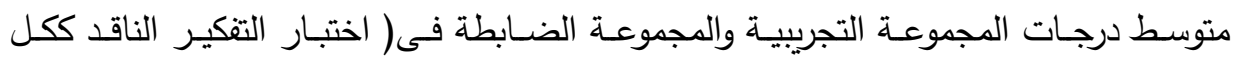
والتحصيل الدراسى) لصالح المجموعة التجريبية. 


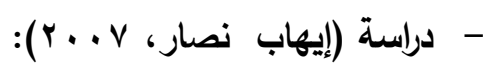

دراسة هدفت إلي التعرف على أثر استخدام الألغاز في تتمية التنكير الناقد في الرياضيات والميل

نحوها للى تلاميذ الصف الرابع الأساسي بغزة، وتكون مجتمع الدراسة من جميع طلبة

$$
\text { الصف الرابع }
$$

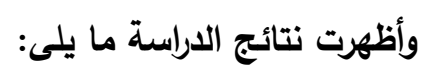

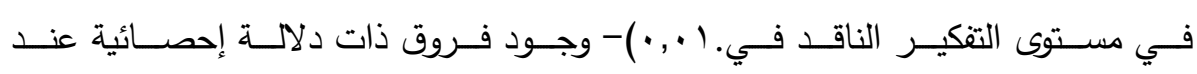

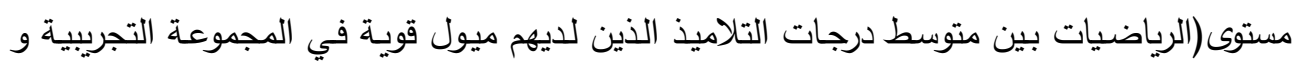
أقرانهم المجموعة الضابطة لصالح تلاميذ المجموعة التجريبية.

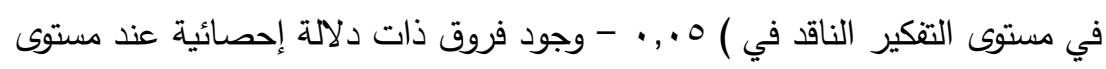

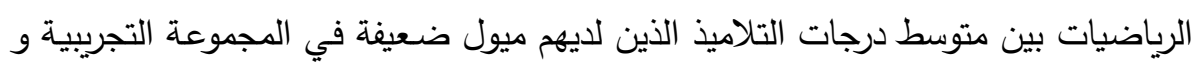

أقرانهم في المجموعة الضابطة لصالح تلاميذ الدجموعة التجريبية.

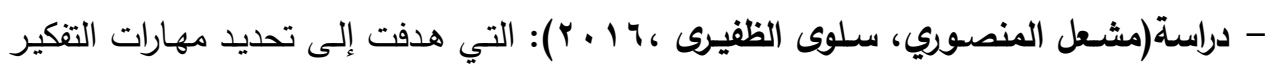

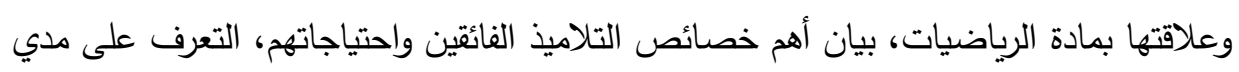

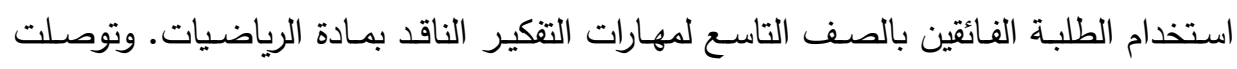

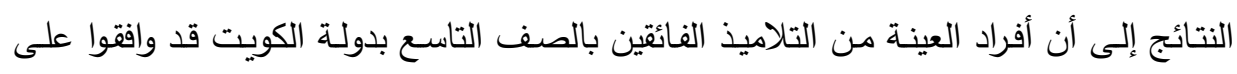

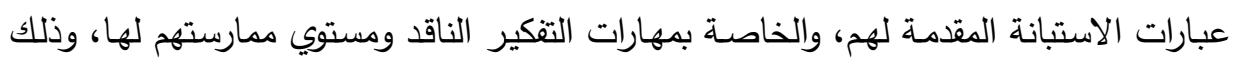
بنسبة موافقة متوسطة.

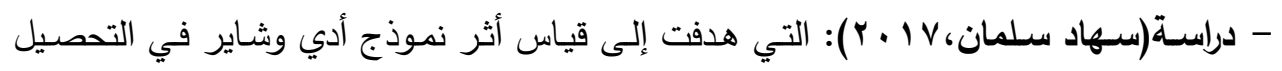

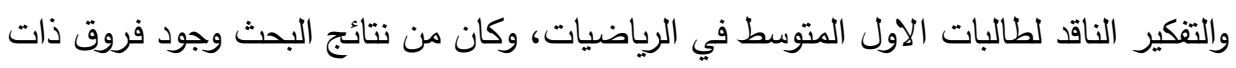

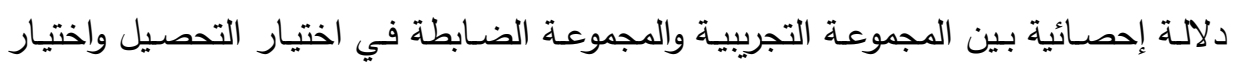

$$
\text { التنكير الناقد ولصالح المجموعة التجريبية. }
$$

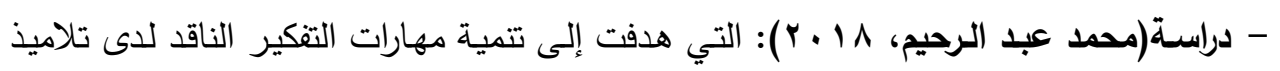

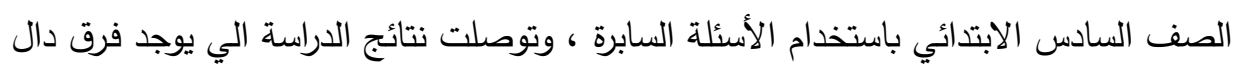

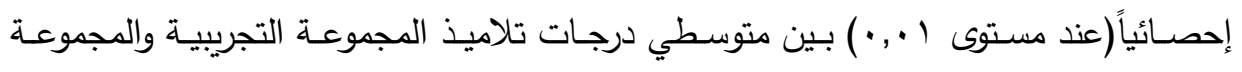

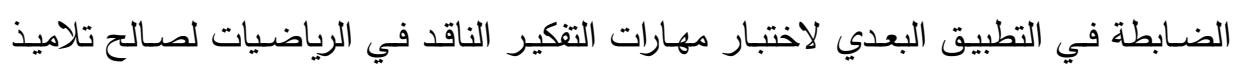




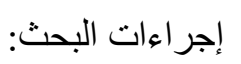

( ) الاطـلاع على البحـوث والدراسـات السـابقة ذات العلاقـة بمتغيـرات البحث، ودراسـة نظريـة لكتغيرات البحث وهي مهارات التفكير الناقد في الرياضيات. r

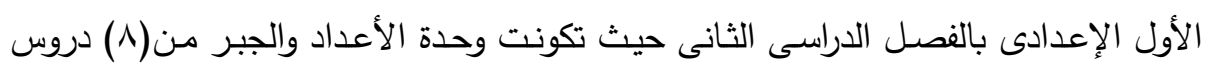
وتكونت وحدة الهندسة والقياس من(^) دروس مجالاً للبحث.

؟) اختيار عينة البحث وتقسيمها الى مجموعتين إحداهما تجريبية والأخرى ضابطة. ع) تطبيق اختبار السعه العقلية على تلاميذ المجموعتين التجريبية والضـابطة قبل بدء التدريس وتحديد أعداد التلاميذ مرتفعي/ منخفضي السعه العقلية فى كل مجموعة. 0) إعداد دليل المعلم في وحدتي البحث (الأعداد والجبر ، الهندسة والقياس ) باستخدام استراتيجية

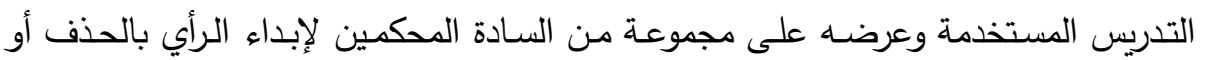
التعديل أو الإضافة. 7) إعداد كراسـة الأنشطة في الوحدات المختارة من مقرر الرياضيات للصف الأول الإعدادي وعرضها على مجموعة من السادة المحكمين لإبداء الرأي بالحذف أو التعديل أو الإضافة.

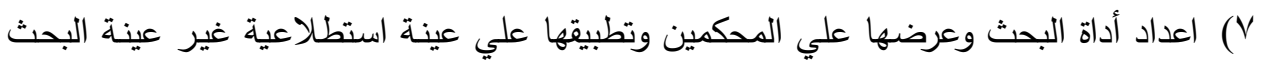
الاساسية. ^) تطبيق أداة البحث قبلياً علي تلاميذ المجموعتين التجريبية والضابطة.

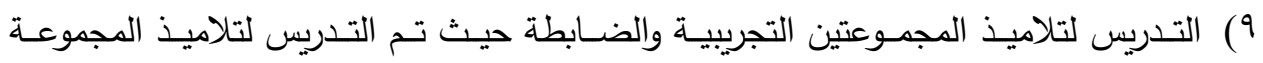
التجريبية باستخدام استراتيجية العصف الذهني التعاوني وفي نفس الوقت التدريس لتلاميذ المجموعة الضابطة باستخدام الطريقة المعتادة في التدريس. • (1)إعـادة تطبيـق اختبـار التفكيـر الناقد في الرياضـيات بعـد الانتهـاء مـن التـدريس لتلاميذ

$$
\text { المجموعتين مباشرة. }
$$
(1) (1) تحليل نتائج البحث ومناقشتها وتئنة.

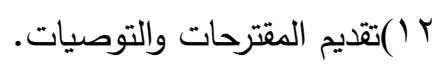

خطوات اعداد اختبار التفكير الناقد في الرياضيات: ( ) تحديد الهدف من الاختبار : هدف هذا الاختبار إلى قياس المهارات الفرعية للتفكير الناقد في

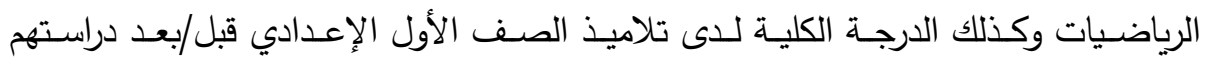


لوحدتي(الأعداد والجبر ،الهندسة والقياس) وقياس فعالية استراتيجية العصف الذهني التعاوني في تتمية تلك المهارات في الرياضيات.

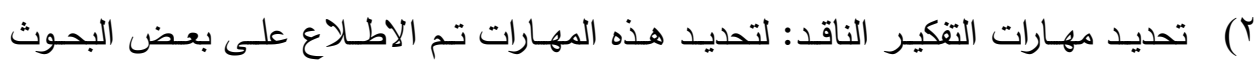

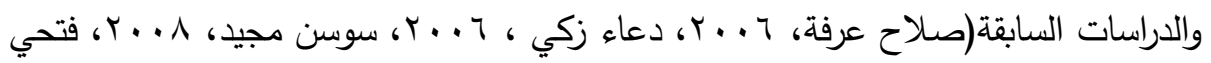

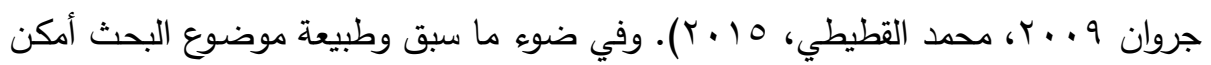

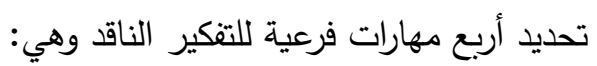

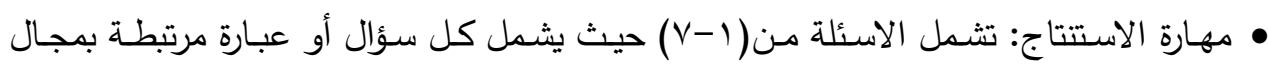
تدريس الرياضيات في الصف الأول الإعدادي يليها أربعة بدائل والمطلوب من الطالب اختئل الطيار البديل الذى يتفق مع مقدمة كل سؤال. • مهارة التفسير : تثمل الاسئلة من(^-ـ ( ) حيث اشتمل كل سؤال على قضية مرتبطة بمجال

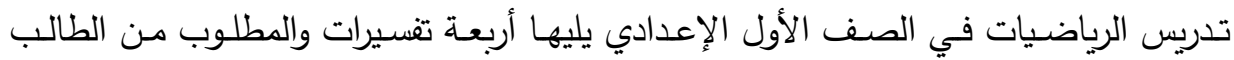
اختيار التفسير المناسب الذى يتفق مع المقدمة أو القضية.

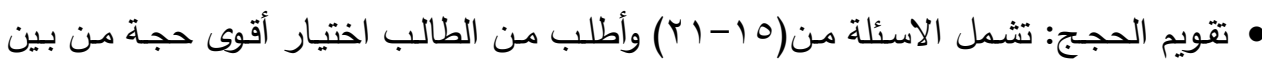
الحجج الأربع المعطاه في كل سؤال.

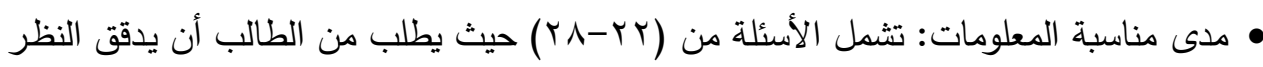

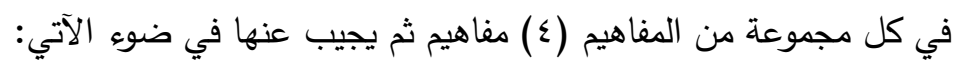
- ما المفهوم غير المناسب في كل مجموعة من المفاهي阝؟

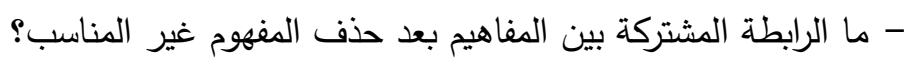

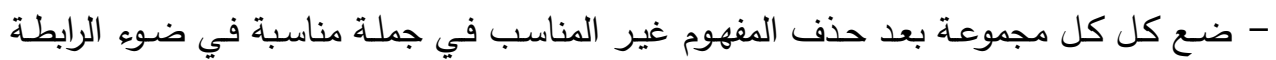

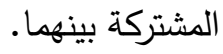
r) صياغة مفردات الاختبار : تم وضـع أسئلة الاختبار في صورة الاختيار من متعدد للثلاث مهارات الأولى(مقدمة+؛ بدائل لكل سؤال). ؛) وضع تعليمات الاختبار ثم وضع تعليمات للاختبار ككل لتوضيح المطلوب من الطالب ثم لمال إعطاء مثال توضيحي لكيفية الإجابة عن أسئلة الاختبار . 0) تقدير درجات الاختبار حيث يعطى كل سؤال درجة واحدة في حالة الإجابة الصحيحة،

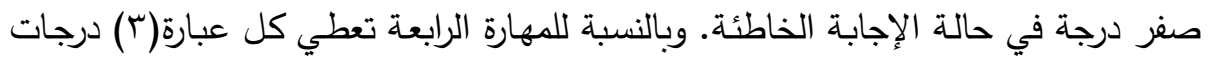


بحيث تعطي درجة عن كل نقطة صحيحة وصفر في حالة الاجابة الخاطئة وبذلك تصبح

$$
\text { الدرجة النهائية للاختبار (r ع) درجة. }
$$

- جدول المواصفات لاختبار التفكير الناقد في صورته النهائية: تكون الاختبار من (Y^) مفرده

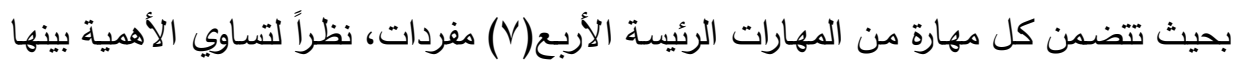

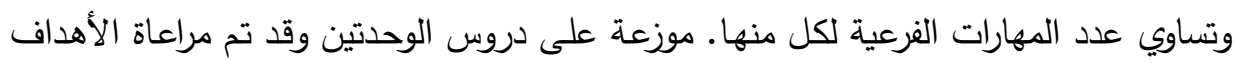

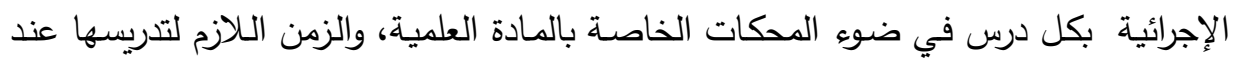
إعداد مفرات الاختبارويوضح جدول( (1) توصيف اختبار التنكير الناقد من حيث مهارات التنكير الناقد وأرقام المفردات لكل مهارة.

\section{جدول (1)}

جدول المواصفات الخاص باختبار التفكير الناقد في الرياضيات

\begin{tabular}{|c|c|c|c|c|}
\hline الدرجة الكلية & درجة كل سؤال & عدد الأسئلة & أرقام الأسئلة & 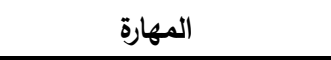 \\
\hline V & 1 & V & $v-1$ & الاستتتاج \\
\hline V & 1 & V & $1 \leqslant-\lambda$ & التفسير \\
\hline V & 1 & V & $r 1-10$ & تقويم الحجج \\
\hline r) & r & 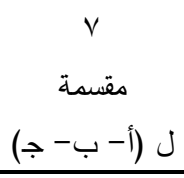 & $r \Lambda-r r$ & تحديد مدى مناسبة المعلومات \\
\hline$\varepsilon r$ & & rᄉ & rA & المجموع \\
\hline
\end{tabular}

\) التجربة الاستطلاعية لاختبار التفكير الناقد:

بعد التأكد من صدق اختبار التفكير الناقد، تم تطبيقه على عينة استطلاعية عددها (79) تلميذاً من تلاميذ الصف الثاني الاعدادي من مدرسة طلخا الاعدادية الجديده وتم تصحيح اختبار التنكير الناقد، ورصد درجات التلاميذ. (V تحديد الزمن اللازم للإجابة عن اختبار التفكير الناقد:

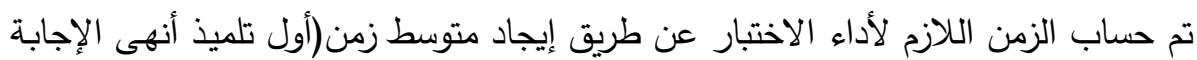
عن مفردات الاختبار ، وأخر تلميذ أنهى الإجابة عن نفس الاختبار ):

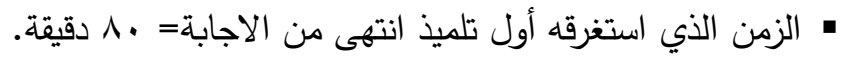
• الزمن الذي استغرقه أخر تلميذ انتهى من الاجابة= ل . . 1 دقيقة. 
• زمن إلقاء التعليمات = • ( دقيقة.

يتضح- مما سبق - أن الزمن اللازم لتطبيق اختبار مهارات التفكيرالناقد هو ( . . ( ) دقيقة.

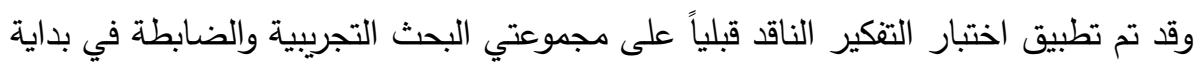

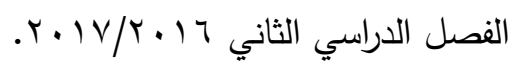

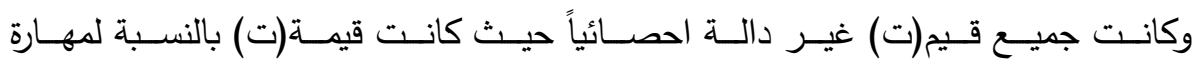
الإسـتتتاج(

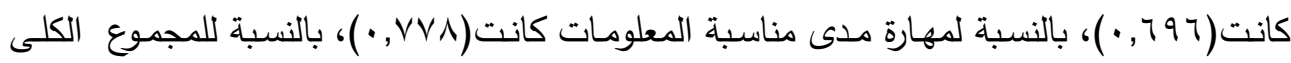

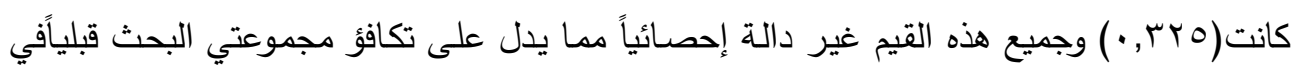
اختبار التفكير الناقد. - حساب ثبات اختبار التفكير الناقد: تم حساب معامل الثبات باستخدام معادلة ألفا كرونباخ حيث تم حساب ثبات كل مهارة على التى حدة مع الدرجة الكلية لاختبار التفكير الناقد والتى يوضحها الجدول التالي: بالي جدول(r)

\begin{tabular}{|c|c|c|c|c|c|}
\hline الاختبار الكلي & مدى مناسبة المعلومات & تقويم & التفسير & الاستنتاج & المهارة \\
\hline •, & $\cdot, \wedge q$. & •, $\Sigma V Y$ & א & , OKT & كرونباخ \\
\hline
\end{tabular}

يتضح من الجدول السابق أن قيم معامل الثبات كما اسفرت عنها معادلة الفا كرونباخ تتراوح

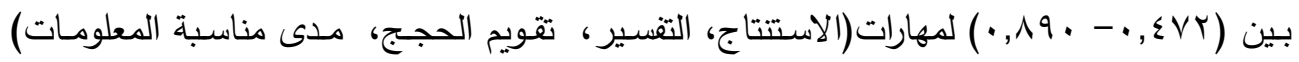

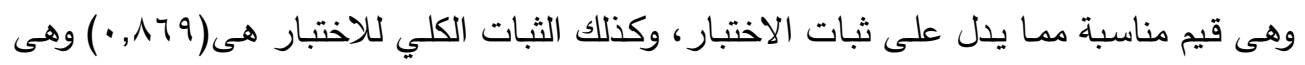
قيمه مناسبة مما يدل على ثبات الاختبار وبذلك أصبح الاختبار صالحا للتطبيق على عينة البحث الأساسية.

كما تم حساب معامل الارتباط بين درجات مفردات كل مفردة مع درجة كل بُعد من الابعاد

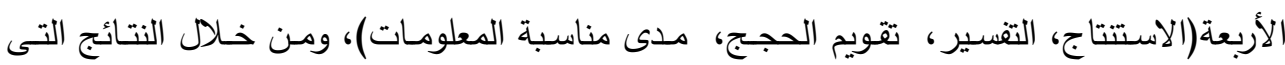

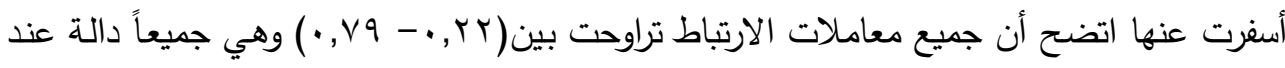

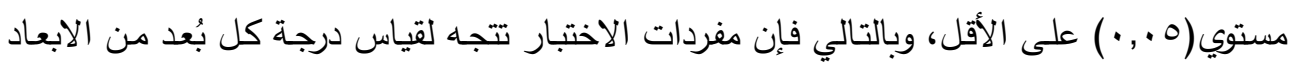


الاربعة، ولتحديد مدي اتساق الابعاد ، والدرجة الكلية لاختبار التفكير الناقد، تم حساب معاملات الارتباط بين درجة كل بُعد والدرجة الكلية للاختبار .

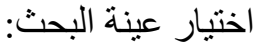

تم اختيار مدرستي طلخا الاعدادية الجديدة، السـلام للتعليم الاساسى بالروضـة التابعتين

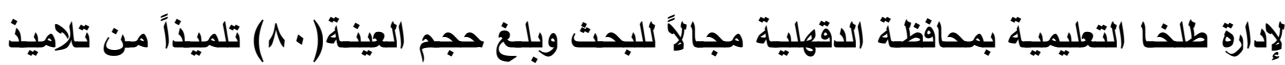
الصف الصف الأول الإعدادي، بواقع ( • ؛ ) للمجموعة التجريبية و( • ؛ ) للمجموعة الضـابطة وتم تقسيمهم الى مجموعتين داخليتين بعد تطبيق اختبار السعة العقلية تطبيقاً قبلياً فقط وتم التقسيم على حسب مستويات السعة العقلية وهما مستويين: أ- مستوى مرتفع ويبلغ عدد تلاميذ هذا المستوى( (ب تلميذ). ب- مستوى منخفض ويبلغ عدد تلاميذ هذا المستوى(9 (19 تلميذ). ويتضح ذلك من الجدول التالي:

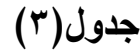

\begin{tabular}{|c|c|c|c|c|}
\hline المجمو & المجموعة & المجموعة & \multicolumn{2}{|c|}{ المجموعة } \\
\hline$\varepsilon r$ & ا Y تلميذ & ا Y تلميذ & مرتفع & \multirow[t]{2}{*}{ السعة العقلية } \\
\hline$r \Lambda$ & 9 19 تلميذ & 9 19 تلميذ & ضنخف & \\
\hline$\Lambda$. & $\varepsilon$. & $\varepsilon$. & & العدد الكلى \\
\hline
\end{tabular}

- - للاجابة عن السؤال الأول من أسئلة البحث، وهو:

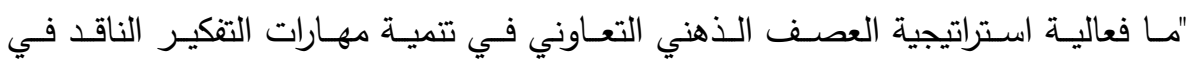

الرياضيات لدى تلاميذ الصف الأول الإعدادي بغض النظر عن مستوي السعه العقلية لديهج؟" حيث يرتبط ذلك بالتحقق من صحة الفرض الأول من فروض البحث وهو: "يوجد فرق دال

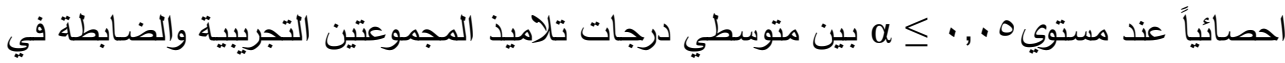

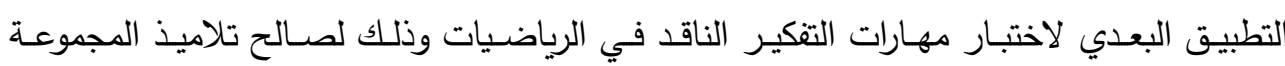
التجريبية"

تـم حسـاب المتوســات الحسـابية والانحرافـات المعياريـة لـدرجات تلاميـذ المجمـوعتين

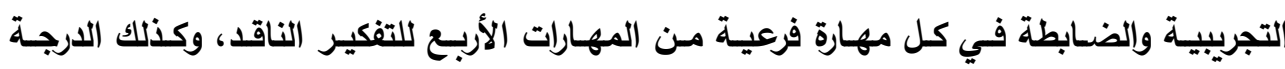


الكليـة(القياس البعدى)، واسـتخدام معادلـة (ت) لحسـاب دلالـة الفروق بـين متوسطات درجـات

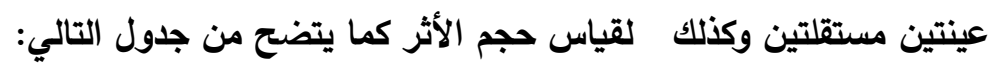

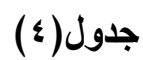

دلالة الفرق بين متوسطي درجات تلاميذ المجموعتين التجريبية والضابطة في اختبار التفكير

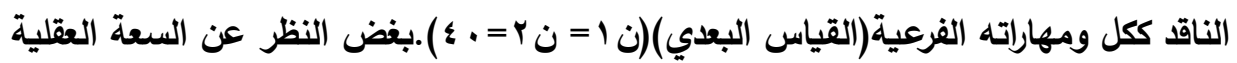

\begin{tabular}{|c|c|c|c|c|c|c|c|c|c|}
\hline \multirow[t]{2}{*}{ الآثر } & \multirow[t]{2}{*}{ ايتا' } & \multirow[t]{2}{*}{ مستوى الالالة } & \multirow[t]{2}{*}{ ت } & \multicolumn{2}{|c|}{ التجموعه التجربية } & \multicolumn{2}{|c|}{ المجموعة } & \multirow[t]{2}{*}{ العظمى الدرجة } & \multirow[t]{2}{*}{ للتفهير الناقد الفرعية } \\
\hline & & & & ع & קי & $\varepsilon$ & ip & & \\
\hline كبير & $\cdot, 7 \mathrm{~V}$ & $\cdot, \cdot 1$ & $1 Y, 04$ & $1, \cdot 1$ & $7,1 \times 0$ & 1,1 & $r, 7$ & V & الإستتتاج \\
\hline كبير & . & $\cdot, \cdot+1$ & $11, r_{7}$ & $1, Y_{T}$ & 7,1 & $1, r_{0}$ & $r, 7$ & V & التفسير \\
\hline كبير & $\cdot, 7$. & $\cdot, \cdot 1$ & $1 \cdot, \wedge 9$ & $\cdot 90$ & 0,90 & $\cdot, 91$ & $r, o v$ & V & تقويم الحجج \\
\hline كبير & $\cdot, 0$. & $\cdot, \cdot, 1$ & $\Lambda, \vee 0$ & $r, 19$ & 10,9 & r,q7 & $9, \wedge$ & rI & 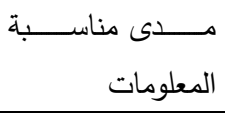 \\
\hline كبير & $\cdot, \wedge)$ & $\cdot, \cdot, 1$ & $\mid \Lambda, r V$ & $r, v$ & $r_{0, \varepsilon}$ & $r, 0$ & $r \cdot, O V$ & $\varepsilon r$ & الدرجة الكلية \\
\hline
\end{tabular}

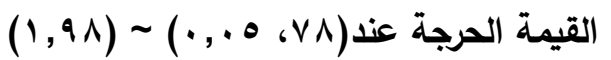

$$
\begin{aligned}
& \text { يتضح من الجدول السابق أنه: }
\end{aligned}
$$

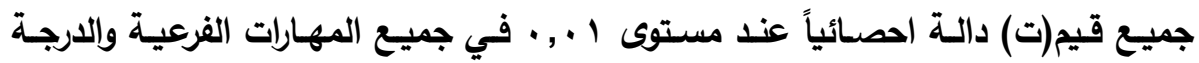

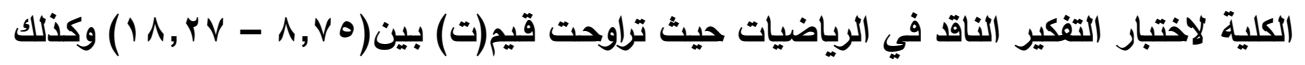

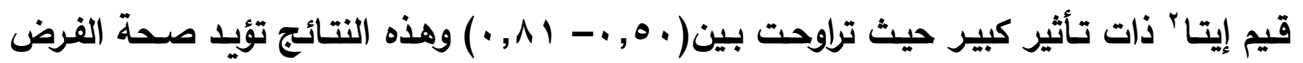

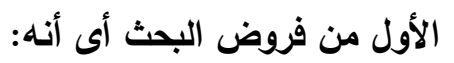

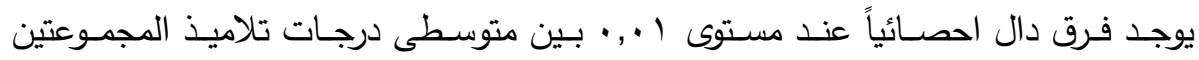

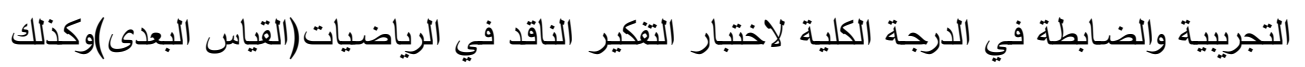
جميع المهارات الفرعية لصالح تلاميذ المجموعة التجريبية(بغض النظر عن مستوي السعة العقلية).

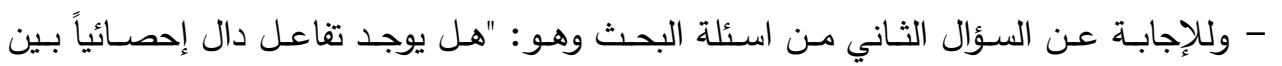

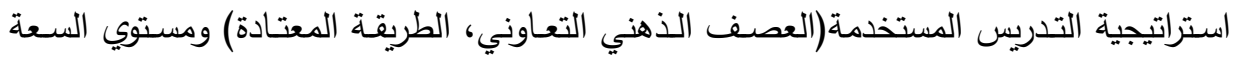
العقلية(مرتفع/منخفض) في تتمية مهارات التفكير الناقد لاى تلاميذ الصف الأول الإعدادي؟ 
حيث يرتبط ذلك بالتحقق من صحة الفرض الثاني من فروض البحث وهو "يوجد تفاعل دال احصائياً عند مستوي ه ., • $\alpha$ بين استراتيجية التدريس ومستوي السعة العقلية في تتمية مهارات

$$
\text { التفكير الناقد في الرياضيات لاى تلاميذ الصف الأه الأول الإعدادي". }
$$

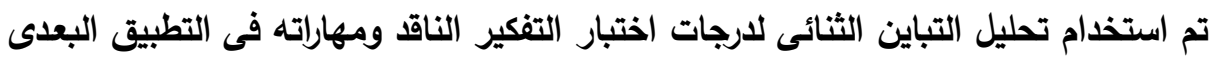
كما يتضح من جدول التالي:

جدول(0)

تحليل تباين ثنائي الاتجاه لارجات تلاميذ عينة البحث في التطبيق البعدى لاختبار التفكير الناقد ومهاراته الفرعية

\begin{tabular}{|c|c|c|c|c|c|c|}
\hline مستوى الدلادي & قيمة ف & المتوسعات & الرجاتة & المزبعوت & مصدر التباين & التفكير الناقد \\
\hline$\cdot, \cdot 1$ & $171, Y T$ & $197, \mathrm{~V}$ & 1 & $197, \mathrm{~V}$ & الإستراتيجية & \multirow[t]{5}{*}{ الاستتتاج } \\
\hline غيردالة & $\cdot, 0$ & $\cdot, \cdot 71$ & $T$ & $\cdot, \cdot 71$ & السعة العقلية & \\
\hline \multirow[t]{3}{*}{ غيردالة } & $\cdot, \cdots$ & $\cdot, \cdots$ & 1 & $\cdot, \cdots$ & الإستراتيجية × السعة & \\
\hline & & $T, Y Y$ & $\frac{V T}{V T}$ & $q \pi, \cdot r$ & الخطا & \\
\hline & & & $\sqrt{19}$ & $r \wedge q, \vee q 1$ & المجموعات & \\
\hline$\cdot, \cdot 1$ & 1 ro, ro & $r \cdot r, \cdot V$ & 1 & $r \cdot r, \cdot V$ & الإستراتيجية & \multirow[t]{5}{*}{ التقسير } \\
\hline غيردالة & $\cdot, 1 K r$ & $\cdot, 199$ & $T$ & $\cdot, 199$ & السعة العقلية & \\
\hline \multirow[t]{3}{*}{ غيردالة } & $\cdot, \Gamma, T$ &., $01 \pi$ & $T$ &., $01 \pi$ & الإستراتيجية × السعة & \\
\hline & & $1,7 r$ & $\overline{V T}$ & $T r Y, Y \Lambda$ & الخطا & \\
\hline & & & $\mathrm{Vq}$ & TYV,.TY & المجموعات & \\
\hline$\cdot, \cdot 1$ & $117,9 \pi$ & $1 \cdot 9,91$ & 1 & $1.9,91$ & الإستراتيجية & \multirow{5}{*}{ تقويم الحجج } \\
\hline غيردالة & $r, \cdot r$ & 1,91 & $T$ & 1,91 & السعة العقلية & \\
\hline \multirow[t]{3}{*}{ غيردالة } & $\cdot, \cdots$ & $\cdot, \ldots$ & $T$ & $\cdot, \ldots$ & الإستراتيجية × السعة & \\
\hline & & $\cdot, 9 \leqslant \varepsilon$ & $V 7$ & V1, vo & الخطا & \\
\hline & & & $\sqrt{99}$ & INr,OV & المجموعات & \\
\hline$\cdot, \cdot 1$ & $\Lambda \cdot, 7$. & $V \cdot Y, \ldots O$ & 1 & $V \cdot r, \ldots O$ & الإستراتيجية & \multirow{5}{*}{ المعلدي مناســاتة } \\
\hline., .0 & $\Lambda, r q$ & $V Y, \wedge$. & 1 & $V Y, \wedge$. & السعة العقلية & \\
\hline \multirow[t]{3}{*}{ غيردالة } & $\cdot, 7 \leqslant$ & 0,09 & 1 & 0,09 & الإستراتيجية × السعة & \\
\hline & & $\overline{\Lambda, \vee 1}$ & $\overline{V 7}$ & 771,10 & الخطا & \\
\hline & & & $\sqrt{19}$ & $1 \leq \varepsilon Y, 1 \leqslant 0$ & المجموعات & \\
\hline$\cdot, \cdot 1$ & 101,7 & $\varepsilon Y O \Lambda, I V$ & 1 & $\varepsilon r O \Lambda, I V$ & الإستراتيجية & \multirow[t]{5}{*}{ الدرجة الكلية } \\
\hline., .0 & $9, r q$ & $\| r, O V$ & $T$ & $11 Y, O V$ & السعة العقلية & \\
\hline \multirow[t]{3}{*}{ غير دالة } & $\cdot, Y Y Y$ & $r, 7 \Lambda$ & 1 & $r, T \Lambda$ & الإستراتيجية × السعة & \\
\hline & & $1 r, 11$ & $V 7$ & $9 T \cdot, r \leqslant$ & الخطا & \\
\hline & & & $\sqrt{99}$ & OYqY,TT & المجموعات & \\
\hline
\end{tabular}

يتضح من الجدول السابق أنه لايوجد تفاعل دال احصائياً بين استراتيجية التدريس والسعة

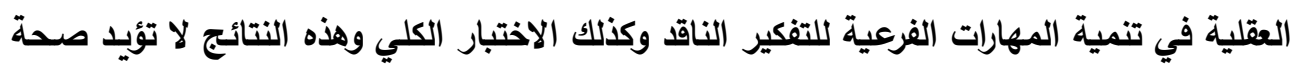
الفرض الثانى من فروض البحث أى أنه: "لا يوجد تفاعل دال احصائياً بين استراتيجية التدريس ومستوي السعة العقلية في تنمية مهارات التفكير الناقد للتطبيق البعدي في الرياضيات لاى تلاميذ الصف الأول الإعدادي". 
تفسير ومناقشة النتائج الخاصة بالتفكير الناقد في الرياضيات. استخدام المعلم لاستراتيجية العصف الذهني التعاوني ساعد في:

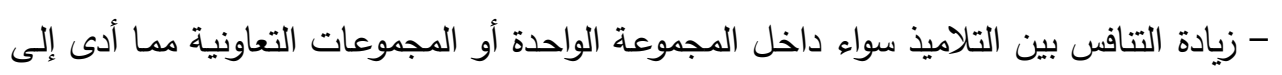
توليد العديد من الأفكار لحل المسائل الرياضية، كما أن كل تلميذ كان يبنى أفكاره على أفكار زملائه ثم يطورها إلى الأفضل. - كما أن حرية التفكير التى أعطيت للتلاميذ ساعدتهم على استتباط أفكار جديدة وإثارة تفكيرهم

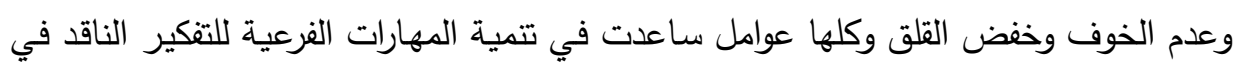

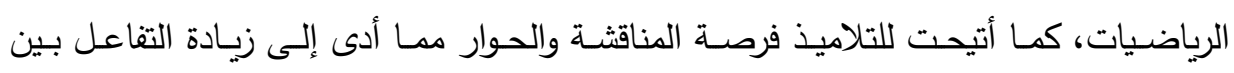
التلاميذ وزيادة الثقة بالنفس وتتمية اتجهاتهم نحو الرياضيات.

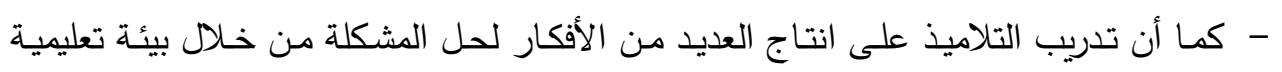
نشطة تتوفر فيها الطمأنينة ونبذ الخلاف الفردى والتأكيد على قبول الأفكار غير المقبولة وعدم

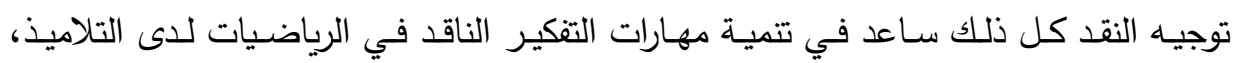

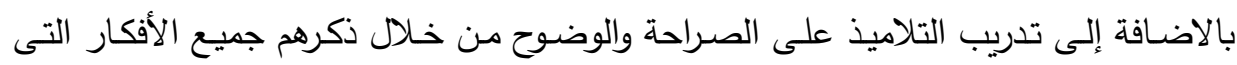
يعتقدون أن لها صلة بالمشكلة. - كما أن تعريف كل تلميذ بدوره داخل المجموعة أدى الى تحمله المسئولية والثعور بالانتهـاء الحقيقى للجماعة ومن ثم بذل أقصى جهد لنجاح عمل المجموعة بالإضـافة إلى الوصول إلى دلى قرارات جماعية لأفراد كل مجموعة. - كما أن طرح العديد من الأسئلة الثفهية على المجموعات التعاونية ذات الصياغة المحددة مثل:

ماذا يحدث لو....؟ كيف......؟ متى....؟ أين.....؟ علل......؟ وهذه الاسئلة ساعدت في: تثخيص مواطن القوة والضعف لدى التلاميذ، واثارة انتباههم واصغائهم للمعلم، واعادة انضباط التلاميذ المشاغبين في الحصة، وتوجيه تفكيرهم نحو المستويات المعرفية العليا وحفزهم

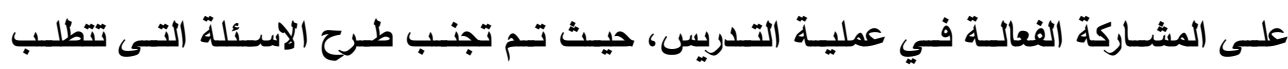

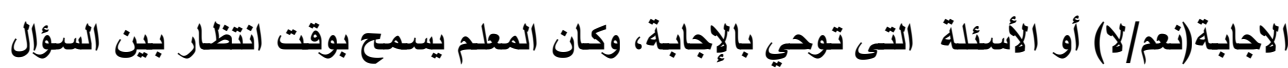

استخدام التغذية الراجعة وأساليب التعزيز المعنوي والمادي في بعض الأحيان من شأنه أن يحفز التلاميذ، ويشير دافعيتهم للتعلم، مما ينمى مهارات التفكير الناقد لديهم. 
وتتفق مع هذه النتائج مـع نتائج العديد من الدراسات التى استخدمت استراتيجيتى العصف

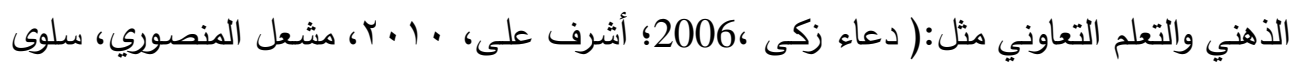

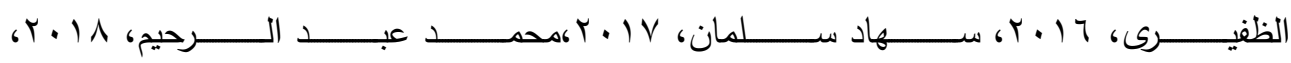

.(Leader,Middleton,2004

أما عن عدم وجود تفاعل دال احصائياً بين استراتيجية التدريس ومستوى السعة العقلية في تتمية مهارات التتكير الناقد في الرياضيات فيعود إلى ما يأتى:

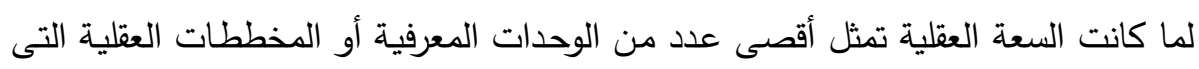
يستطيع الفرد التعامل معها أوتتاولها في وقت واحد فقد يكون الاندفاع لدى التلاميذ وليس التروى

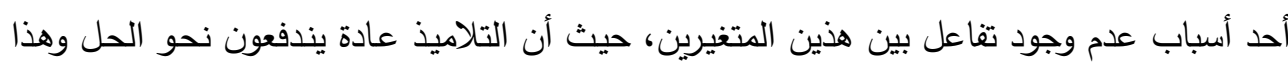

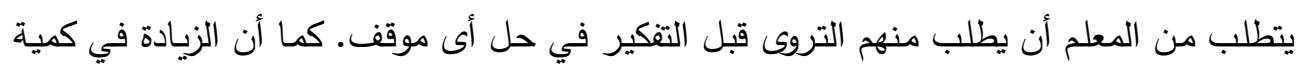

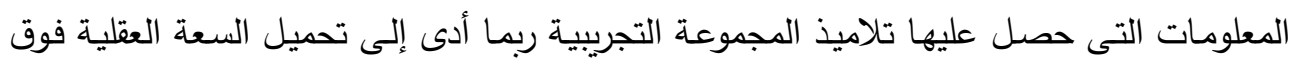
طاقتها وبالتالى لم يوجد تفاعل دال احصائياً بين استراتيجية التدريس ومستوى السعة العقلية(عالَ)

فى ضوء ما أسفر عنه البحث الحالي من نتائج، فإن الباحث يقدم التوصيات التالية:

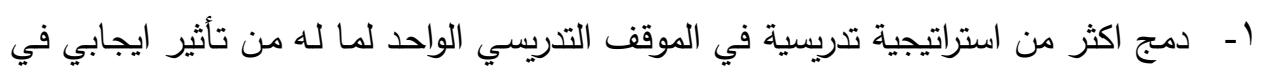

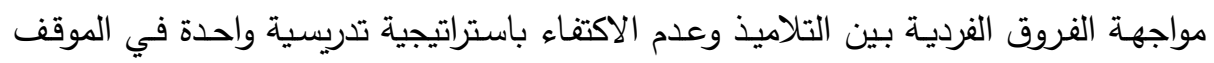

$$
\text { التدريسي الواحد. }
$$

r- تدريب معلمي الرياضيات علي توظيف استراتيجية العصف الذهني الجماعي عند تدريس

$$
\text { موضوعات الرياضيات. }
$$

r- يجب الاهتمام بتروي التلاميذ اثناء حل مسائل الرياضيات حيث دلت نتائج البحث علي عدم

وجود تفاعل بين استراتيجية التدريس ومستوي السعة العقلية للتلاميذ.

$$
\text { بحوث مقترخة: }
$$

في ضوء نتائج البحث يمكن اقتراح المزيد من الدراسات والبحوث ومنها:

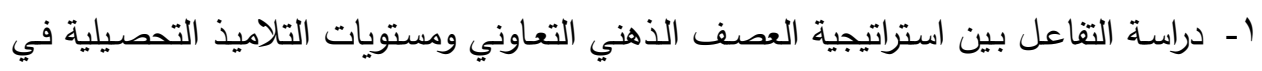

الرياضيات في تتمية أنواع أخري من التنكير مثل التفكير الابداعي والجانبي.

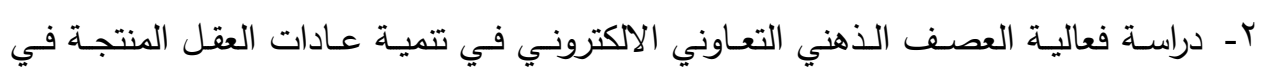

الرياضيات لدي تلاميذ المرحلة الاعدادية. 


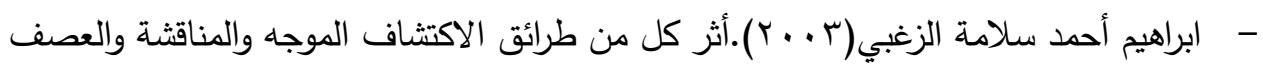

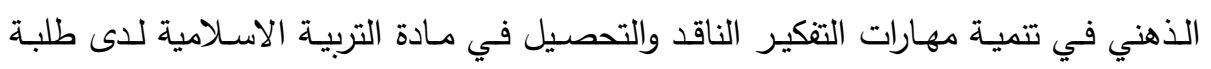

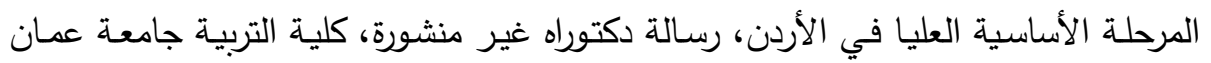

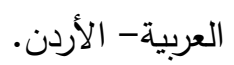

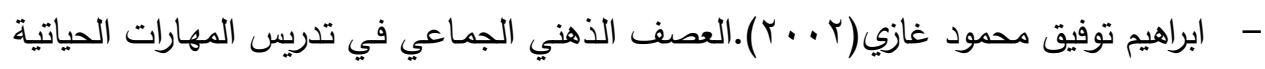
والبيئية لتتمية مهارات طرح الأسئلة، المؤتمر العلمي السـادس بالاسماعية- التربية العلميـة

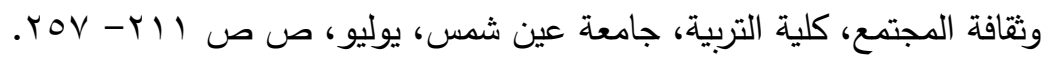

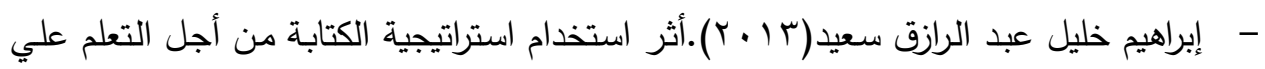
تتمية بعض مهارات التفكير الناقد والتحصيل في الرياضيات لاى تلاميذ المرحلة الابتدائية، رسالة ماجستير غير منشورة، كلية التربية، جامعة بني سويف.

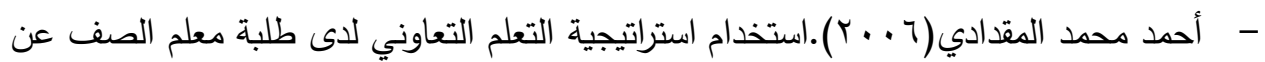

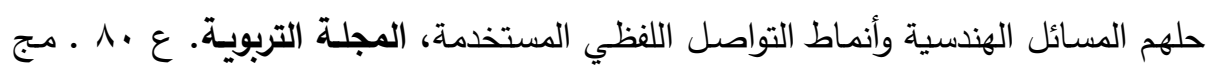
.$r$.

- أشرف راشد علي( • ( • ؟).أثر استخدام التدريس التبادلي في تدريس الهندسة على تتمية

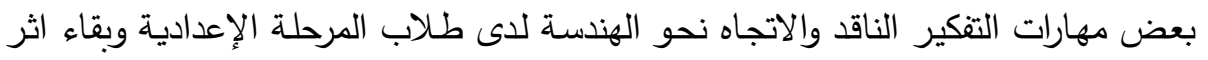

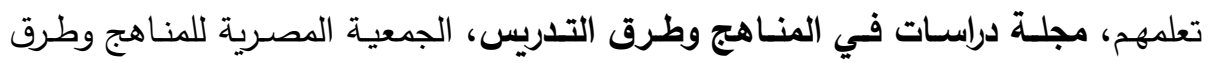

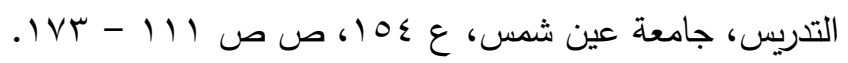

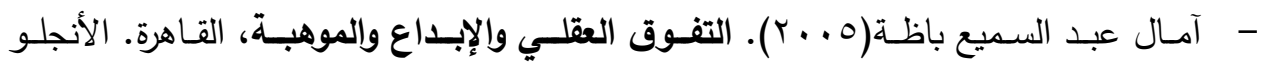
المصرية.

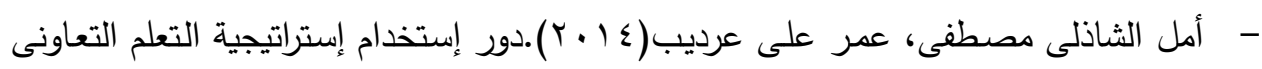

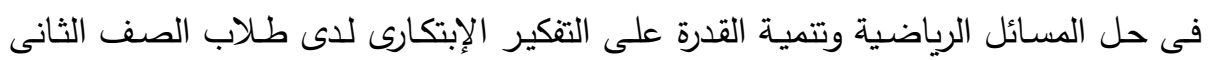

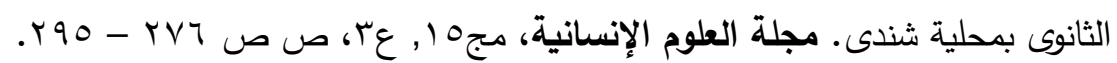

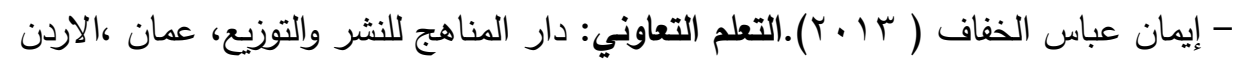

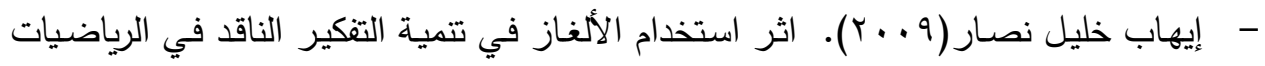

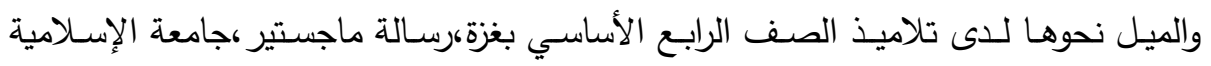
كلية التربية. 


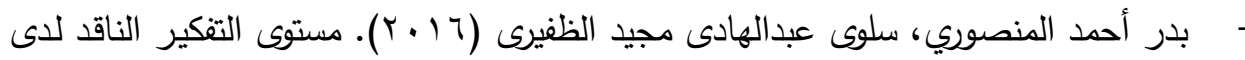

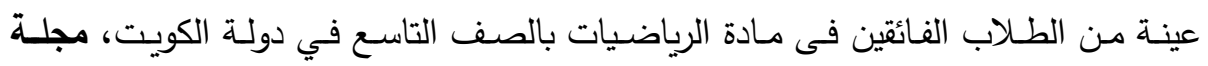

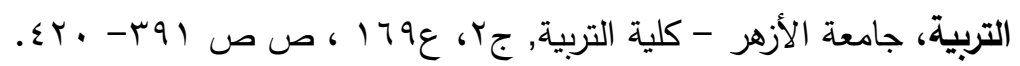

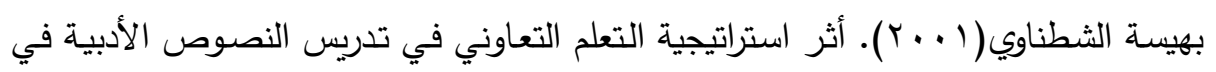

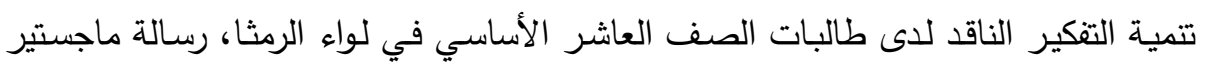
غير منشورة، كلية التربية، جامعة اليرموك، الأردن.

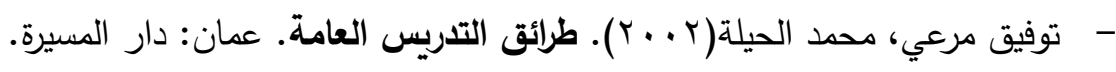

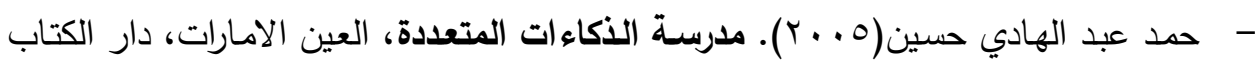
الجامعي. - خولة هاشم حسين(r ( • ب). فاعلية أسلوب العصف الذهني في تحصيل طلبة المعهد التقني

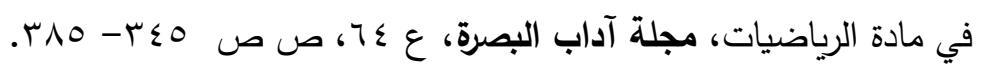

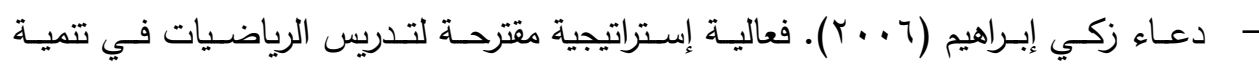

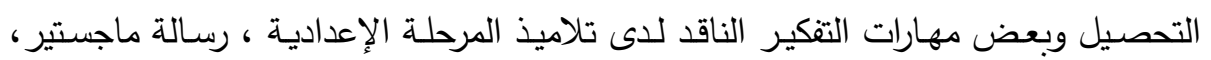
كلية التربية بنها , جامعة بنها. - - رشا نبيل إبراهيم(0 10 ب): فاعلية برنامج مقترح قائم على المدخل البصري في تتمية التفكير

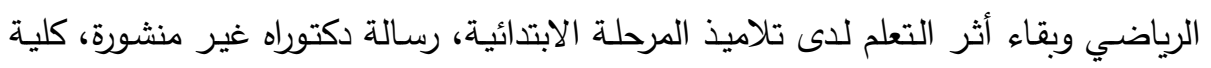
التربية،جامعة الزقازيق.

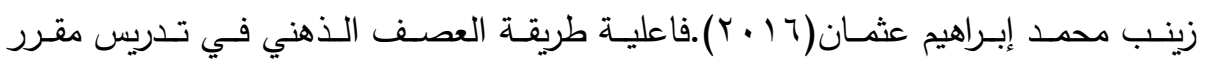
الرياضيات لطلاب الصف الثاني الثانوي، رسالة ماجستير، كلية التربية، جامعـة السودان للعلوم والتكنولوجيا. - سامية إبراهيمى(Y ( • Y).أثر استراتيجية التعلم التعاوني : لنتعلم معا على اكتساب المفاهيم

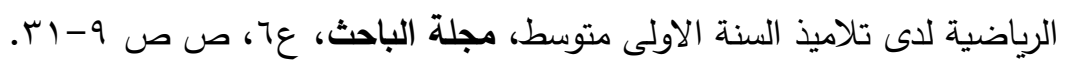

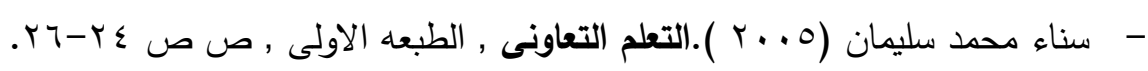

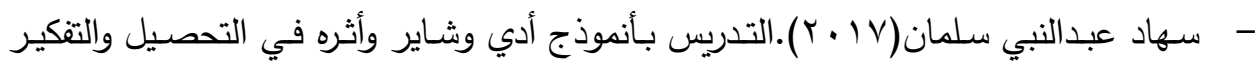

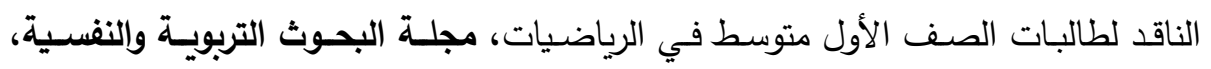

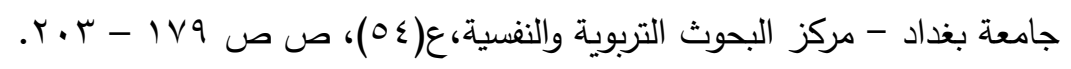

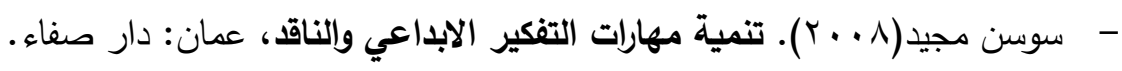




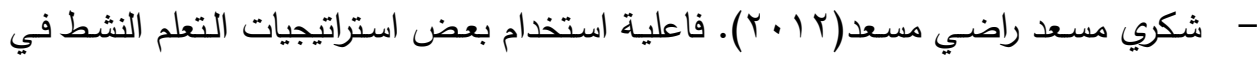

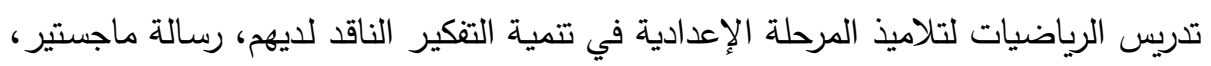
معهد الدراسات التربوية، جامعة القاهرة.

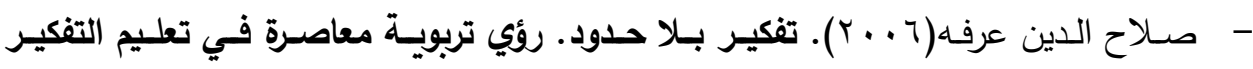
وتعلمه، القاهرة: عالم الكتب.

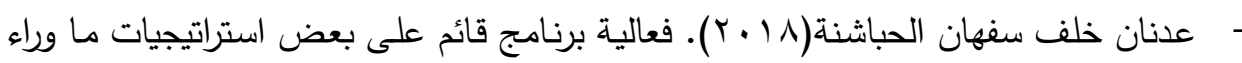

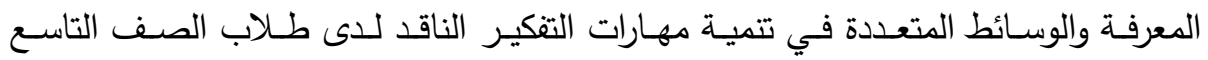
الأساسي بالأردن،مجلة كلية التربية، ع(r • ( ). عدنان يوسف العتوم(ع + . ؟). علم النفس المعرفي" النظرية وإلتطبيق" عمان، دار المسيرة. علاء الدين أحمد كفافي وآخرون(r . r). مهارات الاتصال والتفاعل في عمليتي التعليم والتعلم، دار الفكر للطباعة.

عمر محمود غباين(r . . r). تطبيقات مبتكرة في تعليم التفكير، عمان. دار جهينة.

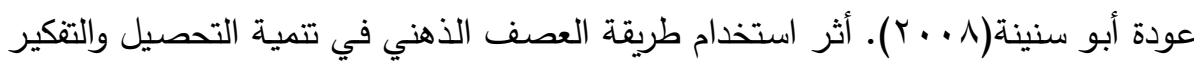

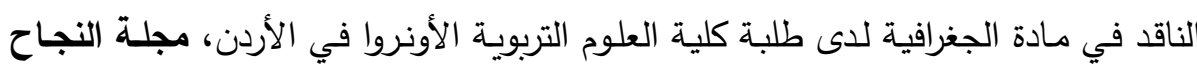

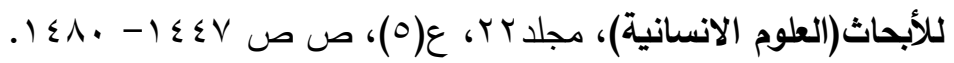

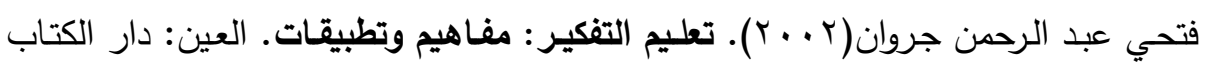

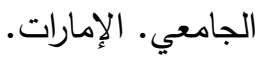
- فتحي عبد الرحمن جروان(9 ؟). تعليم التفكير" مفاهيم وتطبيقات" طه، عمان: دار الفكر للنشر والتوزيع.

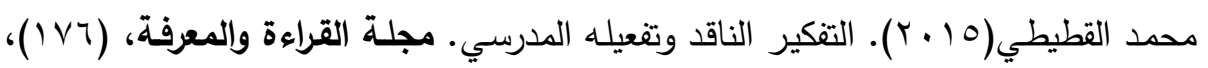

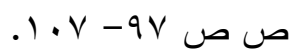

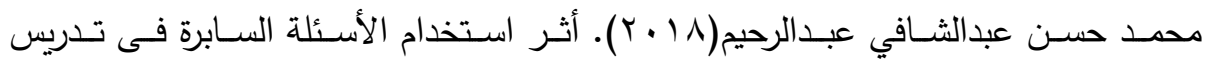
الرياضيات على تتمية مهارات التثكير الناقد لدى تلاميذ المرحلة الإبتدائية، مجلة تربويـات

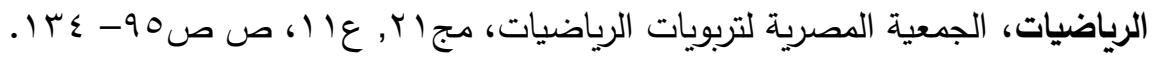

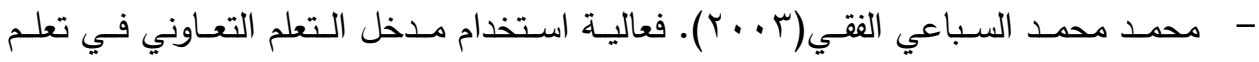
الرياضيات لدى فئات الطلاب التحصيلية المختلفة بالصف الخامس الابتدائي، مجلة كلية التربية . ع r ع. 


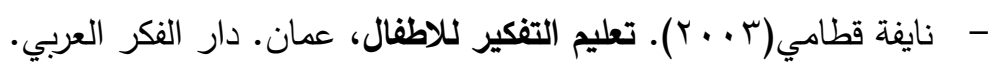

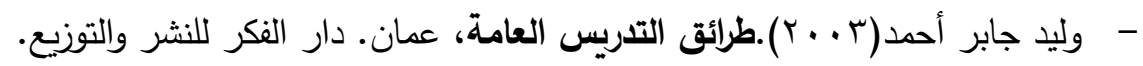

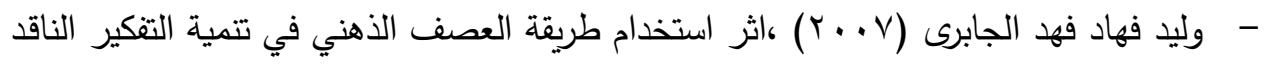

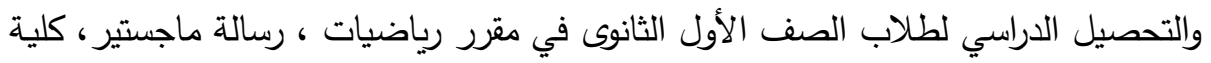

$$
\begin{aligned}
& \text { التربية ، جامعة أم القرى، مكة المكرمة. }
\end{aligned}
$$

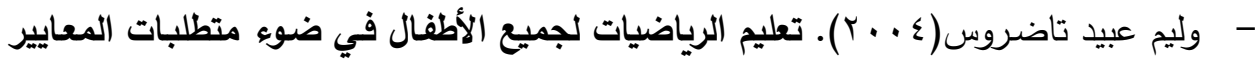

$$
\begin{aligned}
& \text { وثقافة التفكير. عمان: دار الفكر العربي. }
\end{aligned}
$$

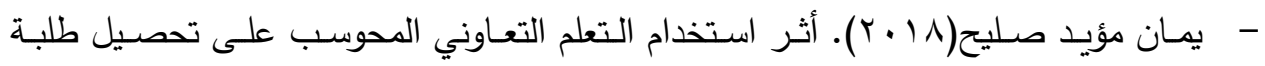

$$
\begin{aligned}
& \text { الصف الثامن الأساسي في مادة الرياضيات، مجلة العلوم التربوية والنفسية، المركز القومي } \\
& \text { للبحوث غزة، مج ب، عء، ص ص ل 1-17. }
\end{aligned}
$$

- Christina, B. (2004). "Looking beyond your own trash can". School Arts, Vol (103),Jan.P.48.Education,China.

- Damico, J.(2005).Multiple dimensions of literacy and conceptions of readers: Toward a more expansive view of accountability. The Reading Teacher.Vol(58).No(7),April ,PP. 644-652.

- Ennis, R. (2004): A Super Streamlined Conception of Critical Thinking Retrieved. May 5. 2006 Form: http://www.CriticalThinking.Org. 17/4/2016. 3.PM

- Fleming, grace (2011): Brainstorming Techniques, for Left from:http:/www.worksimp.com/articles/creativity\% 20in\% 20 problem\% 20solving .pdf. 15/3/2016.5.PM.

- Glazer, E (2003), Technology Enhanced Learning Environments that are Conducive to Critical Thinking in Mathematics :Implications for Research about Critical Thinking on the World Wide Web Avaliable at:http: // www.arches .uga.edu/. eglazer/ EDIT 6400. html.Retrievedon :12 September 2003.

- Sondel .H.B.(2009). The Effect of Curricular Programs on Aspects of Critical Thinking as Applied to Writing .ED, University of Virginia, AAT3364889. Available from: Pro-Quest Database.

- Manktelow , James \& Carlson Amy (2011): Brainstorming Generating Many Radical Creative Ideas , Mind Tools Ltd, Available at: http ://www.mindtools.com, Retrievied on 17,5,2011 
- Maw, C. K. (2006): The effect of award-giving and Brainstorming Education, effectiveness in the development of metacognition skills and the achievement of science among high school students with different mental capacities. China

- Nagel, p. (2008). Moving beyond lecture: copperative learning and the secondary social studies classroom. Journal of Education.Vol 128 N(3): PP.363-368.

- NCTM, (2000). Principles and standards for school mathematics reaction, va the council

- Weinstien , M., 2005: "Critical Thinking and Education for Democracy", Educational Philosophy and Theory, Vol.23.N(10). 15/3/2016.5.PM.

,from:http:/www.worksimp.com/articles/creativity \%20in \% 20

problem\% 20solving .pdf. 